\title{
De arbeidsmarkt voor kenniswerkers
}

\author{
Citation for published version (APA):
}

Marey, P. S., Diephuis, B. J., Dupuy, A., Dijksman, S., \& Golsteyn, B. H. H. (2002). De arbeidsmarkt voor kenniswerkers. Researchcentrum voor Onderwijs en Arbeidsmarkt, Faculteit der Economische Wetenschappen. ROA Reports No. 9 https://doi.org/10.26481/umarep.2002009

Document status and date:

Published: 01/01/2002

DOI:

10.26481/umarep.2002009

Document Version:

Publisher's PDF, also known as Version of record

\section{Please check the document version of this publication:}

- A submitted manuscript is the version of the article upon submission and before peer-review. There can be important differences between the submitted version and the official published version of record.

People interested in the research are advised to contact the author for the final version of the publication, or visit the DOI to the publisher's website.

- The final author version and the galley proof are versions of the publication after peer review.

- The final published version features the final layout of the paper including the volume, issue and page numbers.

Link to publication

\footnotetext{
General rights rights.

- You may freely distribute the URL identifying the publication in the public portal. please follow below link for the End User Agreement:

www.umlib.nl/taverne-license

Take down policy

If you believe that this document breaches copyright please contact us at:

repository@maastrichtuniversity.nl

providing details and we will investigate your claim.
}

Copyright and moral rights for the publications made accessible in the public portal are retained by the authors and/or other copyright owners and it is a condition of accessing publications that users recognise and abide by the legal requirements associated with these

- Users may download and print one copy of any publication from the public portal for the purpose of private study or research.

- You may not further distribute the material or use it for any profit-making activity or commercial gain

If the publication is distributed under the terms of Article $25 \mathrm{fa}$ of the Dutch Copyright Act, indicated by the "Taverne" license above, 


\section{De arbeidsmarkt voor kenniswerkers}

ROA-R-2002/9

Philip Marey

Bart J. Diephuis

Arnaud Dupuy

Sander Dijksman

Bart Golsteyn

Researchcentrum voor Onderwijs en Arbeidsmarkt

Faculteit der Economische Wetenschappen en Bedrijfskunde Universiteit Maastricht

Maastricht, juni 2002 
ISBN 90-5321-338-4

\author{
Sec02.054.doc
}




\section{Inhoud}

Bladzijde

Voorwoord

1 Inleiding 1

2 De huidige situatie op de arbeidsmarkt voor kenniswerkers 3

2.1 Definities van kenniswerkers 3

2.2 Opleidingsachtergronden en beroepsuitoefening van kenniswerkers 6

2.3 Huidige schaarste op de arbeidsmarkt voor kenniswerkers 9

3 Prognoses arbeidsmarkt voor kenniswerkers tot $2006 \quad 13$

$\begin{array}{ll}3.1 \text { Inleiding } & 13\end{array}$

$\begin{array}{ll}3.2 \text { Uitbreidingsvraag } & 14\end{array}$

$\begin{array}{ll}3.3 \text { Vervangingsvraag } & 16\end{array}$

$\begin{array}{ll}3.4 \text { Baanopeningen } & 19\end{array}$

$\begin{array}{lll}3.5 & \text { Arbeidsmarktinstroom } & 21\end{array}$

3.6 Verwachte knelpunten in de personeelsvoorziening naar beroep 23

4 Kenniswerkers in de publieke en private sector $\quad 27$

$\begin{array}{ll}4.1 \text { Inleiding } & 27\end{array}$

4.2 Knelpunten in de personeelsvoorziening van bedrijfssectoren 28

4.3 Crowding out op de arbeidsmarkt voor kenniswerkers 30

4.4 Opleidingsachtergronden van onderzoekers naar bedrijfssector 31

4.5 Studierichtingen van onderzoekers met een TU-opleiding naar $\begin{array}{ll}\text { bedrijfssector } & 33\end{array}$

4.6 Crowding-out-effecten: empirische resultaten 34

4.7 Knelpunten in de personeelsvoorziening van universiteiten tot $2008 \quad 36$

4.8 Lonen van TU-ingenieurs in de publieke en private sector 39

5 Buitenlandse kenniswerkers in Nederland $\quad 41$

6 Kenniswerkers in het buitenland 43

6.1 De Nederlandse arbeidsmarkt voor kenniswerkers in internationaal perspectief 43

6.2 De internationale arbeidsmarkt voor kenniswerkers 46

7 Conclusie $\quad 51$

$\begin{array}{ll}\text { Literatuur } & 53\end{array}$ 



\section{Voorwoord}

De kenniseconomie is van cruciaal belang voor de concurrentiekracht van de Nederlandse economie. De arbeidsmarkt voor kenniswerkers legt echter beperkingen op aan het innovatief vermogen van de Nederlandse economie. Tekorten aan bepaalde groepen kenniswerkers kunnen een remmende werking hebben op innovatieprocessen. Aangezien aanpassingsprocessen aan de aanbodzijde van de arbeidsmarkt voor kenniswerkers vaak langzaam verlopen, vanwege de vele jaren scholing en training die vereist zijn, is het van belang om tijdig inzicht te hebben in huidige en toekomstige knelpunten op de arbeidsmarkt voor kenniswerkers, zodat snel en bij voorkeur preventief gehandeld kan worden door beleidsmakers, werkgevers en onderwijsinstellingen. Met dit rapport wordt beoogd hieraan een bijdrage te leveren door het in beeld brengen van de Nederlandse arbeidsmarkt voor kenniswerkers, waarbij zowel zal worden ingegaan op de huidige situatie als de verwachte ontwikkelingen tot 2006.

Dit rapport is geschreven in opdracht van het cluster Scholing \& Arbeidsmarkt van de Directie Infrastructuur \& Innovatie van het Ministerie van Economische Zaken. Aan dit rapport is meegewerkt door Bart J. Diephuis, Arnaud Dupuy, Sander Dijksman en Bart Golsteyn. De projectleiding was in handen van Philip Marey. De auteurs danken het Koninklijk Instituut van Ingenieurs (KIvl) voor het beschikbaar stellen van de KIvl Salarisenquête. 



\section{Inleiding}

De kenniseconomie staat volop in de belangstelling en speelt een centrale rol in discussies over de concurrentiekracht van de Nederlandse economie. Menselijk kapitaal is daarbij van doorslaggevende betekenis. Kennis wordt door mensen gegenereerd, overgedragen en toegepast. Het potentieel aan menselijk kapitaal biedt grote mogelijkheden voor innovaties. Een beperking aan het innovatief vermogen van de Nederlandse economie wordt echter opgelegd door de arbeidsmarkt voor kenniswerkers. Schaarste aan bepaalde groepen hoogopgeleiden kunnen innovatieprocessen afremmen en daarmee ook de economisch groei op lange termijn. Het kan zelfs tot gevolg hebben dat Nederlandse bedrijven hun kennisintensieve activiteiten naar het buitenland verplaatsen en dat buitenlandse bedrijven andere landen prefereren als vestigingsplaats boven Nederland. Hierbij speelt een rol dat aanpassingsprocessen aan de aanbodzijde van de arbeidsmarkt voor kenniswerkers vaak traag zijn omdat de benodigde scholing en training vaak vele jaren vergen. Internationale arbeidsmobiliteit kan een snellere oplossing bieden, maar houdt ook een risico in: via de internationale arbeidsmarkt voor kenniswerkers stromen niet alleen mensen in, maar ook uit.

Het doel van dit rapport is het in kaart brengen van de arbeidsmarkt voor kenniswerkers. Enerzijds wordt reeds beschikbaar cijfermateriaal op een samenhangende wijze gepresenteerd vanuit het perspectief van de arbeidsmarkt voor kenniswerkers, anderzijds zijn ook nieuwe data gegenereerd door het ROA om lacunes in het bestaande cijfermateriaal op te vullen en zo een beter inzicht in de arbeidsmarkt voor kenniswerkers te verkrijgen. Hierbij gaat het met name om de opleidingsachtergronden en beroepsuitoefening van kenniswerkers (hoofdstuk 2). Daarnaast worden ook prognoses voor de arbeidsmarkt voor kenniswerkers tot 2006 gepresenteerd (hoofdstuk 3), die gebaseerd zijn op de meest recente prognoses voor de arbeidsmarkt voor schoolverlaters van het ROA in De arbeidsmarkt naar opleiding en beroep tot 2006 (ROA, 2001). Hiermee wordt een beeld gegeven van de knelpunten in de personeelsvoorziening die op de middellange termijn verwacht worden. Verder zal worden ingegaan op de crowding-out-effecten die kunnen optreden wanneer verschillende bedrijfssectoren in een concurrentieslag verwikkeld zijn om een beperkte groep kenniswerkers (hoofdstuk 4). De bijdrage die buitenlandse kenniswerkers leveren aan het verlichten van knelpunten en crowdingout-effecten wordt ook besproken (hoofdstuk 5). Tenslotte wordt een schets gegeven van de Europese arbeidsmarkten voor kenniswerkers, die zowel als 'benchmark' voor de Nederlandse situatie dient als aangeeft wat de mogelijkheden voor internationale arbeidsmobiliteit van kenniswerkers zijn (hoofdstuk 6). 



\section{De huidige situatie op de arbeidsmarkt voor kenniswerkers}

\subsection{Definities van kenniswerkers}

Er bestaan verschillende definities voor kenniswerkers, waarbij onderscheid is te maken tussen ruime definities en enge definities van kenniswerkers. Het onderscheid tussen de twee soorten definities heeft betrekking op de verschillende bijdragen aan het innovatief vermogen van de economie. Onder innovatie verstaan $w^{1}$ vernieuwingen van producten, diensten of processen door het toepassen van nieuwe of recente technologie. Bij producten en diensten komen deze vernieuwingen tot uiting in nieuwe specificaties of gebruiksmogelijkheden. Bij processen zijn de vernieuwingen af te meten aan de lagere proceskosten of grotere productieprestaties. Cörvers (1999) onderscheidt vier manieren waarop hoogopgeleiden een bijdrage kunnen leveren aan de productiviteit: door het verrichten van R\&D (het onderzoekseffect), het toepassen van nieuwe technologieën (het diffusie-effect), het efficiënt inzetten van de middelen van de organisatie in het productieproces (het allocatie effect) en efficiënt inzetten van de beschikbare middelen in hun eigen werk (het arbeidseffect). Ruime definities van kenniswerkers hebben betrekking op alle mensen die een bijdrage kunnen leveren aan het innovatief vermogen van een economie (alle vier genoemde effecten). Enge definities beperken zich tot mensen die nieuwe kennis scheppen door R\&D (onderzoekseffect). Onder R\&D (research \& development, speur- en ontwikkelingswerk) verstaan $w^{2}$ het vergroten van technisch-wetenschappelijke kennis (fundamenteel onderzoek), het systematisch zoeken naar oplossingen van praktische problemen (toegepast onderzoek) en het systematisch uitwerken van onderzoeksresultaten tot nieuwe of verbeterde producten, diensten of processen (ontwikkeling).

De meest ruime definitie van kenniswerkers is de HRST-groep ('human resources in science and technology', meestal eenvoudig aangeduid als 'HRST', door het CBS ook wel als 'wetenschappelijk en technologisch arbeidspotentieel'). Van de 10 miljoen Nederlanders tussen 18 en 64 jaar in 1999 kan volgens de Enquête Beroepsbevolking (EBB) van het CBS ruim een derde (3,5 miljoen) tot de HRSTgroep worden gerekend (tabel 2.1). Dit deel van de bevolking is op basis van opleidingsachtergrond (HRST-opleiding) of beroepsuitoefening (HRST-beroep) in principe in staat een bijdrage aan het innovatief vermogen van de economie te leveren. Met HRST-opleidingen (vaak aangeduid als 'HRSTE') worden HBO en WO bedoeld. In Nederland bestaat deze groep uit bijna 2,4 miljoen personen (tabel 2.1). Onder HRST-beroepen ('HRSTO') vallen in termen van de Standaard Beroepenclassificatie 1992 (CBS, 1993) de meeste hogere en wetenschappelijke beroepen evenals bepaalde middelbare (technische) beroepen. De exacte definitie van HRSTberoepen is vastgesteld in de Draft Manual on the Measurement of Human

1. Innovatie-enquête van het CBS, zie bijvoorbeeld Kennis en economie 2000 (CBS, 2000).

2. R\&D-enquête van het CBS, zie bijvoorbeeld Kennis en economie 2000 (CBS, 2000). 
Resources devoted to S\&T (OECD, 1993) en is gebaseerd op de International Standard Classification of Occupations 1988 (ISCO) van het International Labour Office (ILO). De HRST-beroepen bestaan uit drie componenten: een deel van de ISCO-1-beroepen (namelijk de 'production and operations department managers', 'other department managers' en 'general managers'), alle ISCO-2-beroepen ('professionals') en alle ISCO-3-beroepen ('technicians and associate professionals'). Niet tot de HRST-beroepen worden derhalve gerekend: de rest van ISCO-1 ('legislators and senior officials', 'directors and chief executives') en ISCO-4 tot en met ISCO-9 en ISCO-0 ('clerks', 'workers', 'operators and assemblers', 'elementary occupations', 'armed forces'). Zoals weergegeven in tabel 2.1 zijn in Nederland ruim 2,5 miljoen mensen werkzaam in een HRST-beroep. Deze mensen worden derhalve geacht een bijdrage aan het innovatief vermogen van de Nederlandse economie te kunnen leveren.

De definitie van HRST-beroepen is zo ruim dat waarschijnlijk veel werknemers die geen bijdrage leveren aan innovatieprocessen toch tot mensen met HRST-beroepen gerekend worden. Uiteraard kunnen hoogopgeleiden met een gamma- of alfaachtergrond een bijdrage leveren aan innovatieprocessen, bijvoorbeeld bij het afstemmen van nieuwe technologieën op de behoeften van de consument. Het is echter twijfelachtig of we dan ook alle gamma- en alfa-wetenschappers - inclusief theologen, maatschappelijk werkers en beleidsmedewerkers personeelszaken - tot de HRST-beroepen moeten rekenen. Tegelijkertijd vallen er voor innovatieprocessen belangrijke personen buiten de HRST-beroepen. Aan de bovenkant van de arbeidsmarkt (ISCO-1) maken 'legislators and senior officials' (ISCO-11) en 'directors and chief executives' (ISCO-121) geen deel uit van de HRST-beroepen. Het gevolg van de definitie van HRST-beroepen is dat Bill Gates (ISCO-121) minder relevant geacht wordt voor innovatieprocessen dan een sportjournalist (ISCO-24). Aan de onderkant van de arbeidsmarkt wordt verondersteld dat er op de werkvloer geen bijdrage aan innovatieprocessen wordt geleverd ('learning-by-doing'). Dergelijke 'bottom-up-innovatie' door assembleurs en operators wordt buiten de definitie van de HRST-beroepen gehouden.

Tabel 2.1

Bevolking 18-64 jaar en HRST-groep (personen), 1999

\begin{tabular}{lrrrrr}
\hline $\begin{array}{l}\text { Beroep/ } \\
\text { Opleiding }\end{array}$ & HRST-beroep & Ander beroep & Werkloos & $\begin{array}{c}\text { Niet in } \\
\text { Beroepsbevolking }\end{array}$ & Totaal \\
\hline HBO-WO & $\mathbf{1 . 3 7 5 . 0 0 0}$ & $\mathbf{6 3 8 . 0 0 0}$ & $\mathbf{4 4 . 0 0 0}$ & $\mathbf{3 1 1 . 0 0 0}$ & 2.368 .000 \\
MBO en lager & $\mathbf{1 . 1 3 8 . 0 0 0}$ & 4.185 .000 & 190.000 & 2.211 .000 & 7.724 .000 \\
Totaal & 2.513 .000 & 4.823 .000 & 234.000 & 2.522 .000 & 10.092 .000 \\
\hline
\end{tabular}

Componenten van de HRST-groep in vetgedrukte cijfers: totaal 3.506.000.

Bron: CBS, Kennis en economie 2001, Tabel 2.4.1

De HRST-groep wordt vastgesteld op basis van een combinatie van opleidingsachtergronden en beroepsuitoefening. We kunnen derhalve drie componenten van de HRST-groep onderscheiden: hoogopgeleiden werkzaam in een HRST-beroep (vaak aangeduid als de 'core' van de HRST, 'HRSTC'), middelbaar en lager 
opgeleiden werkzaam in een HRST-beroep en hoogopgeleiden niet werkzaam in een HRST-beroep. In Nederland bestaan deze componenten uit respectievelijk 1.375.000, 1.138.000 en 993.000 personen (tabel 2.1). Dit betekent dat meer dan een kwart van de HRST-groep (993.000 van de 3.506.000) geen bijdrage levert aan het innovatief vermogen van de Nederlandse economie. Dit onbenutte HRSTpotentieel bestaat per definitie uit mensen met een HBO- of WO-opleiding en is opgebouwd uit drie componenten: 638.000 personen zijn werkzaam in een nietHRST-beroep, 44.000 zijn werkloos en 311.000 maken geen deel (meer) uit van de beroepsbevolking (tabel 2.1).

In hoeverre mensen werkzaam in HRST-beroepen daadwerkelijk bijdragen aan innovatie is zoals eerder opgemerkt niet altijd even duidelijk. Een aanmerkelijk kleinere groep waarvan deze bijdrage aanmerkelijk duidelijker is wordt gevormd door het $\boldsymbol{R} \& \boldsymbol{D}$-personeel. Hieronder verstaan we personen die betrokken zijn bij R\&D waarbij drie groepen onderscheiden kunnen worden. ${ }^{4}$ In de eerste plaats de onderzoekers (door het CBS 'wetenschappers' genoemd ${ }^{5}$, internationaal vaak aangeduid als 'research scientists and engineers' of 'RSE's'), dit zijn alle personen behorend tot de wetenschappelijke onderzoeksstaf. In de tweede plaats de assistenten: op hoog niveau onder supervisie van onderzoekers aan R\&D meewerkend personeel. In de derde plaats het overig ondersteunend personeel, zoals (laboratorium)onderhoudspersoneel, secretariaats-, bibliotheek- en kantoorpersoneel direct werkzaam ten behoeve van R\&D-activiteiten. Uit tabel 2.2 blijkt dat het R\&D-personeel in Nederland uit ruim 105.000 personen bestaat, waarvan bijna 47.000 onderzoekers.

Tabel 2.2

Bevolking 18-64 jaar en definities van kenniswerkers, 1999

\begin{tabular}{lrr} 
Definitie van kenniswerkers & Aantal personen & $\begin{array}{c}\text { Percentage van } \\
\text { bevolking 18-64 jaar }\end{array}$ \\
\hline Bevolking 18-64 jaar & 10.092 .000 & 100 \\
HRST-groep & 3.506 .000 & 35 \\
HRST-beroepen & 2.513 .000 & 25 \\
R\&D-personeel & 105.333 & 1,04 \\
Onderzoekers & 46.793 & 0,46 \\
\hline
\end{tabular}

Bron: CBS, Kennis en economie 2001, Tabel 2.4.1, 3.2.2., 3.2.3, A.3.1.4, A.4.1.10

Een belangrijk onderscheid kan vervolgens gemaakt worden tussen R\&D in publiek gefinancierde kennisinstellingen en R\&D bij bedrijven. Onderzoek in de publieke sector is vaker van fundamentele aard, terwijl bedrijven zich meer concentreren op toegepast onderzoek. In hoofdstuk 4 wordt nader ingegaan op de verschillende typen

3. Volgens de eerder vermelde definitie van de R\&D-enquête van het CBS.

4. R\&D-enquête van het CBS, zie bijvoorbeeld Kennis en economie 2000, (CBS, 2000).

5. In dit rapport hanteren we liever de term onderzoekers omdat we onderscheid willen maken tussen onderzoeksberoepen (onderzoekers die R\&D verrichten) en wetenschappelijke beroepen in de terminologie van de SBC (veelal hoogopgeleiden die op wetenschappelijk niveau werken, zonder R\&D te verrichten). 
R\&D-personeel en de allocatie van R\&D over de publieke en private sector (in het bijzonder tabel 4.1).

Uit het voorgaande blijkt dat er voor zowel ruime als enge definities van kenniswerkers meerdere mogelijkheden zijn. Voorzover in dit rapport reeds beschikbaar cijfermateriaal wordt gepresenteerd zullen we de verschillende definities tegenkomen. Daarnaast bevat dit rapport nieuwe informatie over de opleidingsachtergronden en beroepsuitoefening van kenniswerkers. Hierbij is voor een focus gekozen die nauw aansluit bij het Project Onderwijs-Arbeidsmarkt van het ROA. ${ }^{6}$ We concentreren ons daarbij op twee definities voor kenniswerkers, gebaseerd op de Standaard Beroepenclassificatie 1992 (CBS, 1993). In de eerste plaats mensen werkzaam in hogere en wetenschappelijke beroepen. Omdat deze beroepen grotendeels tot de HRST-beroepen gerekend kunnen worden zullen we de term hogere en wetenschappelijke HRST-beroepen hanteren. In de tweede plaats mensen werkzaam in onderzoeksberoepen. Hieronder verstaan we alle beroepen in de Standaard Beroepenclassificatie die betrekking hebben op de onderzoekers uit de R\&D-enquête. In hoofdstuk 3 zal nader worden ingegaan op de verschillende hogere en wetenschappelijke (HRST-)beroepen en de verschillende onderzoeksberoepen. Om knelpunten op de arbeidsmarkt voor kenniswerkers te identificeren worden verwachte ontwikkelingen in de vraag naar kenniswerkers en onderzoekers vergeleken met de instroom op de arbeidsmarkt uit het HBO en WO.

\subsection{Opleidingsachtergronden en beroepsuitoefening van kenniswerkers}

\section{Hogere en wetenschappelijke HRST-beroepen}

Mensen met een HBO- of WO-opleiding die niet werkzaam zijn in een HRST-beroep kunnen gezien worden als onbenut HRST-potentieel: ze behoren qua opleidingsachtergrond tot de HRST-groep, maar zijn niet werkzaam in een HRST-beroep. Uit tabel 2.1 bleek al dat het hierbij om meer dan een kwart van de HRST-groep gaat. In hoeverre speelt de aansluiting tussen het huidige onderwijssysteem en de arbeidsmarkt voor hoger opgeleiden een rol? In tabel 2.3 en 2.4 is de instroom van HBO- en WO-afgestudeerden in hogere en wetenschappelijke HRST-beroepen, anderhalf jaar na het afsluiten van de studie, weergegeven voor de periode 19982000. Uit tabel 2.3 blijkt dat er voor een aantal HBO-opleidingen sprake is van een aanzienlijke onderbenutting in de zin dat afgestudeerden niet werkzaam zijn in een hoger of wetenschappelijk HRST-beroep. Dit geldt voor bijna de helft van de afgestudeerden met een opleiding $H B O$ tolk en vertaler, $H B O$ landbouw en veeteelt, $H B O$ secretariaat en $H B O$ maatschappelijk werk en hulpverlening. De ernstigste onderbenutting vindt plaats voor $\mathrm{HBO}$ toerisme en recreatie: slechts een derde van de recente afgestudeerden werkt in een hoger of wetenschappelijk HRST-beroep.

6. Zie bijvoorbeeld De arbeidsmarkt naar opleiding en beroep tot 2006 (ROA, 2001). 
Tabel 2.3

Percentage HBO-afgestudeerden werkzaam in hoger of wetenschappelijk HRST-beroep, per opleidingstype, gemiddelde 1998-2000

Opleidingstype

HRST-beroep

$\%$

\section{HBO}

HBO Onderwijs en tolk en vertaler

HBO lerarenopleiding basisonderwijs 95

81

HBO lerarenopleiding natuur en techniek 90

HBO lerarenopleiding economie en maatschappij $\quad 75$

HBO lerarenopleiding lichamelijke opvoeding 78

HBO lerarenopleiding medisch en verzorging 81

HBO lerarenopleiding expressie $\quad 76$

HBO tolk en vertaler 54

HBO Landbouw

$\mathrm{HBO}$ landbouw en veeteelt $\quad 53$

HBO milieukunde en levensmiddelentechnologie $\quad 73$

HBO Techniek

HBO laboratorium $\quad 78$

HBO bouwkunde $\quad 75$

$\begin{array}{ll}\text { HBO civiele techniek } & 81\end{array}$

HBO werktuigbouwkunde $\quad 82$

HBO elektrotechniek $\quad 86$

HBO informatica 94

HBO chemische technologie $\quad 78$

HBO vervoer en logistiek $\quad 70$

HBO Paramedisch

HBO verpleegkunde $\quad 79$

HBO (fysio)therapie $\quad 80$

HBO voeding 64

$\mathrm{HBO}$ radiologie $\quad 94$

HBO Economie

HBO accountancy en bedrijfseconomie $\quad 83$

HBO commerciële economie $\quad 65$

$\mathrm{HBO}$ toerisme en recreatie $\quad 32$

$\begin{array}{ll}\mathrm{HBO} \text { recht en bestuur } & 70\end{array}$

$\mathrm{HBO}$ secretariaat $\quad 52$

$\begin{array}{ll}\mathrm{HBO} \text { bedrijfskunde } & 67\end{array}$

HBO Sociaal-cultureel

$\begin{array}{ll}\text { HBO communicatie en journalistiek } & 78\end{array}$

HBO maatschappelijk werk en hulpverlening 56

HBO Sociaal-cultureel (vervolg)

$\begin{array}{ll}\text { HBO personeel en arbeid } & 75\end{array}$

HBO bibliotheek en documentatie $\quad 69$

HBO Kunst

$\begin{array}{ll}\text { HBO uitvoerende en beeldende kunsten } & 70\end{array}$

HBO Openbare orde en veiligheid

HBO openbare orde en veiligheid

Bron: ROA 
Tabel 2.4 toont het percentage afgestudeerden uit het WO dat werkzaam is in een hoger of wetenschappelijk HRST-beroep. De tabel laat zien dat de overgrote meerderheid van de werkenden met een WO opleiding in een hoger of wetenschappelijk HRST beroep werkzaam is. Alleen WO letteren en WO kunstwetenschappen vertonen een behoorlijke onderbenutting van HRST-potentieel: bijna een kwart van de afgestudeerden is anderhalf jaar na het voltooien van de opleiding niet in een hoger of wetenschappelijk HRST-beroep werkzaam.

Wanneer we tabel 2.3 en 2.4 vergelijken valt op dat de HRST-onderbenutting op HBO-niveau groter is dan op WO-niveau. Dit wordt voor een groot deel veroorzaakt doordat een afgestudeerde uit het WO die werkzaam is in een functie waarvoor eigenlijk een HBO-opleiding voldoende is niet tot het onbenutte HRST-potentieel gerekend wordt. Uiteraard kan dan wel gesproken worden van een onbenut WOpotentieel. Desalniettemin vindt de grootste lekkage van HRST-potentieel plaats onder afgestudeerden uit het $\mathrm{HBO}$.

Tabel 2.4

Percentage WO-afgestudeerden werkzaam in hoger of wetenschappelijk HRST-beroep, per opleidingstype, gemiddelde 1998-2000

\begin{tabular}{lc}
\hline & \\
Opleidingstype & HRST-beroep \\
& $\%$ \\
\hline & \\
WO letteren & 77 \\
WO theologie & 84 \\
WO landbouw en milieukunde & 92 \\
WO wiskunde en natuurwetenschappen & 94 \\
WO bouwkunde & 98 \\
WO civiele techniek & 98 \\
WO werktuigbouwkunde & 95 \\
WO elektrotechniek & 97 \\
WO informatica en bestuurlijke informatiekunde & 97 \\
WO (dier)geneeskunde & 99 \\
WO tandheelkunde & 98 \\
WO farmacie en medische biologie & 96 \\
WO econom(etr)ie & 94 \\
WO bedrijfskunde & 92 \\
WO accountancy en belastingen & 98 \\
WO rechten en bestuurskunde & 93 \\
WO sociale wetenschappen & 87 \\
WO kunstwetenschappen & 76 \\
&
\end{tabular}

Bron: ROA

\section{Onderzoeksberoepen}

Afgestudeerden uit het HBO en WO die in de hogere en wetenschappelijke HRSTberoepen werken leveren een bijdrage aan het innovatief vermogen van de economie. De harde kern van deze groep bestaat uit de onderzoekers, die zich immers bezig houden met het scheppen van nieuwe kennis. Welke opleidingstypen leveren de meeste onderzoekers? In tabel 2.5 worden de belangrijkste opleidingsachtergronden (d.w.z. een aandeel van tenminste $10 \%$ ) weergegeven voor 
een aantal onderzoeksberoepen. Opvallend is de wijdverbreide rol die mensen met een opleiding WO wiskunde en natuurwetenschappen spelen in R\&D. Voor medisch onderzoek is deze groep even belangrijk als WO (dier)geneeskunde. Zelfs bij het economisch en sociaal-wetenschappelijk onderzoek nemen mensen met een opleiding WO wiskunde en natuurwetenschappen nog een belangrijk deel van de R\&D voor hun rekening. Alleen in het (weg- en water-)bouwkundig onderzoek lijkt hun rol beperkt. Deze opleiding speelt een belangrijke rol in R\&D en heeft voor studenten als voordeel dat ze in meerdere onderzoeksberoepen emplooi kunnen vinden.

Tabel 2.5

Belangrijkste opleidingsachtergronden van onderzoeksberoepen, gemiddelde 1997-2000

\begin{tabular}{|c|c|c|}
\hline Onderzoeksberoep & Opleidingstype & eroep \\
\hline \multirow[t]{3}{*}{ Landbouwkundigen } & WO landbouw en milieukunde & $36 \%$ \\
\hline & WO wiskunde en natuurwetenschappen & $18 \%$ \\
\hline & WO elektrotechniek & $10 \%$ \\
\hline Wiskundigen en & WO wiskunde en natuurwetenschappen & $56 \%$ \\
\hline natuurwetenschappers & HBO laboratorium & $12 \%$ \\
\hline \multirow[t]{3}{*}{ Werktuigkundigen } & WO wiskunde en natuurwetenschappen & $26 \%$ \\
\hline & WO werktuigbouwkunde & $24 \%$ \\
\hline & HBO werktuigbouwkunde & $18 \%$ \\
\hline \multirow[t]{2}{*}{ (Weg- en water-)bouwkundigen } & WO bouwkunde & $52 \%$ \\
\hline & WO civiele techniek & $17 \%$ \\
\hline \multirow[t]{4}{*}{ Elektrotechnici } & WO elektrotechniek & $27 \%$ \\
\hline & WO wiskunde en natuurwetenschappen & $21 \%$ \\
\hline & WO werktuigbouwkunde & $13 \%$ \\
\hline & HBO elektrotechniek & $11 \%$ \\
\hline \multirow[t]{3}{*}{ Materiaalkundigen } & WO wiskunde en natuurwetenschappen & $30 \%$ \\
\hline & HBO uitvoerende en beeldende kunsten & $21 \%$ \\
\hline & HBO werktuigbouwkunde & $10 \%$ \\
\hline \multirow[t]{4}{*}{ Medici } & WO wiskunde en natuurwetenschappen & $20 \%$ \\
\hline & WO (dier)geneeskunde & $20 \%$ \\
\hline & WO farmacie & $18 \%$ \\
\hline & WO sociale wetenschappen & $17 \%$ \\
\hline \multirow[t]{3}{*}{ Farmaceuten } & WO farmacie & $59 \%$ \\
\hline & WO wiskunde en natuurwetenschappen & $14 \%$ \\
\hline & WO (dier)geneeskunde & $10 \%$ \\
\hline \multirow{4}{*}{$\begin{array}{l}\text { Economen en sociaal- } \\
\text { wetenschappers }\end{array}$} & WO econom(etr)ie & $17 \%$ \\
\hline & WO sociale wetenschappen & $13 \%$ \\
\hline & WO bedrijfskunde & $12 \%$ \\
\hline & WO wiskunde en natuurwetenschappen & $11 \%$ \\
\hline
\end{tabular}

Bron: CBS/ROA

\subsection{Huidige schaarste op de arbeidsmarkt voor kenniswerkers}

Sinds enige jaren is er sprake van krapte op de Nederlandse arbeidsmarkt. Naast de recente hoogconjunctuur spelen ook structurele ontwikkelingen een rol. Twee demografische trends zijn de 'ontgroening' en 'vergrijzing'. De ontgroening van de arbeidsmarkt betekent een afnemende instroom van schoolverlaters, terwijl vergrijzing duidt op een toenemende uitstroom van ouderen. Daarnaast kunnen 
technologische ontwikkelingen ('skill-biased technical change ${ }^{7}$ ) en de daarmee gepaard gaande organisatorische veranderingen ${ }^{8}$ leiden tot toenemende kwalificatieeisen voor een specifiek beroep. Door dit proces van 'upgrading' komt de krapte vooral tot uiting aan de bovenkant van de arbeidsmarkt. Er zijn dus structurele ontwikkelingen die krapte op de arbeidsmarkt voor kenniswerkers kunnen veroorzaken, zelfs bij een tegenvallende conjunctuur. Tabel 2.6 illustreert deze ontwikkelingen aan de hand van de werkloosheid naar opleidingsniveau in 1994 en 2000.

Tabel 2.6

Werkloosheidspercentage beroepsbevolking naar opleidingsniveau, 1994 en 2000

\begin{tabular}{lcc}
\hline Opleidingsniveau & $\begin{array}{c}1994 \\
\%\end{array}$ & $\begin{array}{c}2000 \\
\%\end{array}$ \\
\hline Basisonderwijs & 17 & 8 \\
VMBO theorie & 12 & 7 \\
VMBO & 10 & 4 \\
HAVO/VWO & 12 & 6 \\
MBO & 6 & 3 \\
HBO & 6 & 3 \\
WO & 7 & 3 \\
Totaal & 8 & 4
\end{tabular}

Bron: CBS/ROA, De arbeidsmarkt naar opleiding en beroep tot 2006, tabel 3.1

Vacatures worden ook vaak als maatstaf voor knelpunten op de arbeidsmarkt gebruikt. Het nadeel van vacaturecijfers is echter dat ze een overschatting geven van de daadwerkelijke hoeveelheid baanopeningen, waarbij die overschatting varieert met de conjunctuur. De Grip, Meijboom \& Willems (1994) onderscheiden drie bronnen van vacatures: uitbreidingsvraag, vervangingsvraag en baan-baanmobiliteit. Baanopeningen bestaan uit uitbreidingsvraag en vervangingsvraag, maar baan-baan-mobiliteit levert geen baanopeningen op voor nieuwkomers op de arbeidsmarkt. Hierdoor geven vacaturecijfers een overschatting van de daadwerkelijke knelpunten op de arbeidsmarkt. Bovendien is de baan-baan-mobiliteit waarschijnlijk relatief hoog in tijden van hoogconjunctuur en relatief laag in een recessie. Daarmee is ook de overschatting van de knelpunten niet constant en dus zijn ook omslagpunten op de arbeidsmarkt moeilijk te identificeren aan de hand van vacaturecijfers. Uit tabel 2.7 blijkt dat de vacaturegraad de kwalitatieve krapte op de arbeidsmarkt minder scherp in beeld brengt: de knelpunten voor hogere en wetenschappelijke beroepen $(1,8 \%)$ lijken van minder ernstige aard dan die voor de overige beroepen, aangezien de arbeidsmarkt als geheel een vacaturegraad van $2,5 \%$ heeft.

7. Zie bijvoorbeeld Machin \& van Reenen (1998).

8. Zie bijvoorbeeld Bresnahan, Brynjolfsson \& Hitt (2001). 
Tabel 2.7

Vacatures naar beroep, 1999

\begin{tabular}{|c|c|c|c|}
\hline & $\begin{array}{c}\text { Werkzame } \\
\text { beroepsbevolking }\end{array}$ & Vacatures & $\begin{array}{c}\text { Vacaturegraad } \\
\%\end{array}$ \\
\hline Totaal & 6.805 .000 & 170.500 & 2,5 \\
\hline $\begin{array}{l}\text { Totaal hogere en } \\
\text { wetenschappelijke } \\
\text { beroepen }\end{array}$ & 1.947 .000 & 35.400 & 1,8 \\
\hline Totaal hogere beroepen & 1.367 .000 & 26.800 & 2,0 \\
\hline Hogere technische beroepen & 163.000 & 4.300 & 2,6 \\
\hline $\begin{array}{l}\text { Hogere economische } \\
\text { beroepen }\end{array}$ & 543.000 & 13.200 & 2,4 \\
\hline $\begin{array}{l}\text { Hogere } \\
\text { managementberoepen }\end{array}$ & 51.000 & 400 & 0,8 \\
\hline $\begin{array}{l}\text { Hogere verzorgende en } \\
\text { sociaal-culturele beroepen }\end{array}$ & 598.000 & 8.000 & 1,3 \\
\hline $\begin{array}{l}\text { Totaal wetenschappelijke } \\
\text { beroepen }\end{array}$ & 580.000 & 8.600 & 1,5 \\
\hline $\begin{array}{l}\text { Wetenschappelijke } \\
\text { technische beroepen }\end{array}$ & 71.000 & 1.300 & 1,9 \\
\hline $\begin{array}{l}\text { Wetenschappelijke } \\
\text { economische beroepen }\end{array}$ & 175.000 & 3.600 & 2,0 \\
\hline $\begin{array}{l}\text { Wetenschappelijke } \\
\text { managementberoepen }\end{array}$ & 100.000 & 1.000 & 1,0 \\
\hline $\begin{array}{l}\text { Wetenschappelijke } \\
\text { verzorgende en sociaal- } \\
\text { culturele beroepen }\end{array}$ & 216.000 & 1.900 & 0,9 \\
\hline
\end{tabular}

Bron: CBS, Kennis en economie 2000, tabel A.2.3.2

Wat zijn de belangrijkste knelpunten op de arbeidsmarkt voor kenniswerkers? Deze vraag wordt in tabel 2.8 beantwoord aan de hand van ontwikkelingen in werkloosheid en lonen van afgestudeerden tussen 1998 en 2000. Een knelpunt zal zich immers uiten in een lage werkloosheid en/of een stijgend loon. ${ }^{9}$ Voor WO economie is de toch al lage werkloosheid in 1998 verder gedaald en zijn de lonen harder gestegen dan voor andere opleidingscategorieën. Voor WO landbouw en techniek is de werkloosheid op hetzelfde lage niveau van $2 \%$ gebleven en zijn de lonen bovengemiddeld gestegen.

De grootste krapte op de arbeidsmarkt voor kenniswerkers lijkt zich dus voor te doen bij economen, technici en landbouwkundigen met een wetenschappelijke opleiding. Hierbij moet worden opgemerkt dat WO landbouw en techniek een zeer heterogene groep is. Derhalve kan de schaarste verschillen per opleidingstype binnen deze opleidingscategorie.

9. Andere uitingsvormen van knelpunten hebben betrekking op de mate waarin mensen beneden hun opleidingsniveau, buiten hun studierichting werken, in hoeverre ze een tijdelijke baan of een deeltijdbaan hebben en de mate van doorstuderen (Wieling \& Borghans, 2001). 
Tabel 2.8

Werkloosheidspercentage en loonstijging afgestudeerden naar opleidingscategorie, 1998 en 2000

\begin{tabular}{|c|c|c|c|c|}
\hline Opleidingscategorie & $\begin{array}{c}\text { Werkloos- } \\
\text { heid } \\
1998 \\
\%\end{array}$ & $\begin{array}{l}\text { Werkloos- } \\
\text { heid } \\
2000 \\
\%\end{array}$ & $\begin{array}{c}\text { Stijging } \\
\text { werkloosheid } \\
1998-2000 \\
\text { procentpunten }\end{array}$ & $\begin{array}{c}\text { Stijging lonen } \\
1998-2000 \\
\%\end{array}$ \\
\hline
\end{tabular}

HBO landbouw en

techniek

$\mathrm{HBO}$ economie

HBO onderwijs en

sociaal-cultureel

HBO paramedisch

WO landbouw en

techniek

WO economie

WO letteren en

sociaal-culturee

WO medisch

2

2
2

$+2$

4

4
3

Totaal

2

2

2

1

5

4

12

3

3

$\begin{array}{rr}0 & +2 \\ 0 & +3 \\ -1 & +4 \\ +1 & +3 \\ & \\ 0 & +4 \\ -1 & +4 \\ -1 & +3 \\ +1 & 0 \\ & \\ 0 & +3\end{array}$

Bron: ROA, De arbeidsmarkt naar opleiding en beroep tot 2006, tabel 3.2 en 3.3

Totale stijging werkloosheid in procentpunten tussen 1998 en 2000; gemiddelde jaarlijkse loonstijging (van het gemiddeld bruto maandloon) tussen 1998 en 2000 gecorrigeerd voor inflatie. 


\section{Prognoses arbeidsmarkt voor kenniswerkers tot 2006}

\subsection{Inleiding}

In het voorgaande hoofdstuk is een beeld gegeven van de huidige situatie op de Nederlandse arbeidsmarkt voor kenniswerkers. Om inzicht te krijgen in toekomstige knelpunten zijn de meest recente arbeidsmarktprognoses van het ROA, die onlangs verschenen in De arbeidsmarkt naar opleiding en beroep tot 2006 (ROA, 2001), verbijzonderd naar HRST-beroepsklassen en onderzoeksberoepsgroepen. Onder HRST-beroepsklassen verstaan we alle hogere en wetenschappelijke beroepsgroepen op het 3-digit-niveau van de Standaard Beroepenclassificatie (SBC) binnen de beroepsklassen van het $\mathrm{ROA}^{10}$, welke vastgesteld zijn op het 2-digitniveau van de SBC. Met onderzoeksberoepsgroepen bedoelen we de wetenschappelijke beroepsgroepen op het 3-digit-niveau van de SBC (met ROAbenaming $^{11}$ ) waaronder de belangrijkste onderzoeksberoepen op 5-digit-niveau vallen. De onderzoeksberoepsgroepen bevatten dus ook HRST-beroepen (op 5-digitniveau), beneden het 3-digit-niveau, waarin geen onderzoek verricht wordt. Aangezien deze beroepen dicht bij elkaar liggen, geven voorspelde knelpunten voor een onderzoeksberoepsgroep toch een goede indicatie van de verwachte schaarste voor de onderzoeksberoepen binnen die onderzoeksberoepsgroep.

De prognoses in De arbeidsmarkt naar opleiding en beroep tot 2006 (ROA, 2001) gaan uit van een werkgelegenheidsontwikkeling in de verschillende bedrijfssectoren van de Nederlandse economie gebaseerd op de korte-termijn-prognoses van het Centraal Economisch Plan 2001 (CPB, 2001) van het CPB tot en met 2002 en het lange-termijn-scenario 'Global Competition' tot 2020 uit de Omgevingsscenario's Lange Termijn Verkenning 1995-2020 (CPB, 1996). De gemiddelde jaarlijkse werkgelegenheidsgroei (in personen) voor de Nederlandse economie als geheel bedraagt in de prognoseperiode $1,2 \%$, meer dan een halvering ten opzichte van de werkgelegenheidsgroei van $2,7 \%$ tussen 1996 en 2000.

De verwachte knelpunten voor HRST-beroepsklassen en onderzoeksberoepsgroepen worden gebaseerd op een confrontatie van baanopeningen en instroom op de arbeidsmarkt voor schoolverlaters als geheel. Hiermee worden substitutieprocessen tussen bijvoorbeeld hoger en middelbaar niveau meegenomen in de analyse van de arbeidsmarkt voor kenniswerkers. De baanopeningen voor schoolverlaters worden veroorzaakt door uitbreidingsvraag ten gevolge van werkgelegenheidsgroei en vervangingsvraag in verband met arbeidsmarktuitstroom. Kandidaten voor deze baanopeningen zijn schoolverlaters en kortdurig werklozen, die in direct concurrentie zijn met elkaar. De verwachte knelpunten worden aangegeven met de 'Indicator Toekomstige Knelpunten in de personeelsvoorziening naar Beroep' (ITKB).

10. Zie ROA-classificatiegids 2002 (ROA, 2002), tabel 5.

11. Zie ROA-classificatiegids 2002 (ROA, 2002), tabel 7. 
In de volgende paragrafen van dit hoofdstuk zullen achtereenvolgens uitbreidingsvraag, vervangingsvraag, baanopeningen, instroom en verwachte knelpunten besproken worden. In elke paragraaf komen eerst de HRST-beroepsklassen in beeld, waarna ingezoomd wordt op de onderzoeksberoepsgroepen.

\subsection{Uitbreidingsvraag}

\section{Uitbreidingsvraag voor HRST-beroepsklassen}

Tabel 3.1 toont een overzicht van de verwachte uitbreidingsvraag voor de periode 2001-2006 (in aantallen en percentages) per HRST-beroepsklasse. Daarnaast is een totaal voor alle HRST-beroepsklassen opgenomen en een totaal voor de gehele arbeidsmarkt, dat wil zeggen inclusief de niet-HRST-beroepen. Het gemiddelde beeld voor de 61 HRST-beroepsklassen wijkt duidelijk af van het totaalbeeld. De totale uitbreidingsvraag naar nieuwe arbeidskrachten binnen de HRST-beroepsklassen bedraagt voor de periode 2001-2006 bijna 229.000 personen. Dit komt neer op een gemiddelde jaarlijkse uitbreidingsvraag ter grootte van $2,2 \%$ van de werkgelegenheid. Het uitbreidingsvraagpercentage voor alle beroepen (inclusief de niet-HRST-beroepen) is, met slechts $1,2 \%$ gemiddeld per jaar, aanzienlijk lager. Het verschil in uitbreidingsvraag tussen de HRST-beroepen en de niet-HRST-beroepen duidt er enerzijds op dat voor sectoren waarin relatief meer HRST-werkers actief zijn een grotere toename in de werkgelegenheid wordt verwacht, en anderzijds geeft het blijk van een toenemende vraag naar hoger opgeleiden in banen waar voorheen middelbaar of lager opgeleiden werden ingezet. Dit laatste wordt wel aangeduid met de term 'upgrading'.

De groep HRST-beroepen als totaal kan voor de periode 2001-2006 duidelijk op meer groei rekenen dan de niet-HRST-beroepen. Voor de meeste HRSTberoepsklassen geldt dat ze een bovengemiddelde uitbreidingsvraag te zien geven. De relatief hoogste uitbreidingsvraag wordt verwacht bij de economischadministratieve HRST-beroepen: liefst 3,3\% gemiddeld per jaar. Met een uitbreidingsvraag van 138.100 arbeidskrachten zijn deze beroepen verantwoordelijk voor ongeveer $60 \%$ van de totale uitbreidingsvraag van HRST-beroepen. Verder geven ook de informatica HRST-beroepen en de sociaal-culturele HRST-beroepen hoge uitbreidingsvraagverwachtingen te zien. Alleen de pedagogische HRSTberoepen geven met slechts $0,7 \%$ gemiddeld per jaar een uitbreidingsvraag te zien welke achterblijt bij het gemiddelde. Er is hier waarschijnlijk dan ook weinig sprake van upgrading.

\section{Uitbreidingsvraag voor onderzoeksberoepsgroepen}

Alle HRST-beroepsklassen hebben volgens tabel 3.1 een positieve uitbreidingsvraag. In hoeverre geldt dit ook in het bijzonder voor de onderzoeksberoepsgroepen? Tabel 3.2 toont een overzicht van de verwachte uitbreidingsvraag voor de periode 2001-2006 (in aantallen en percentages) per onderzoeksberoepsgroep. Met een totale uitbreidingsvraag van 20.400 zijn de onderzoeksberoepsgroepen verantwoordelijk voor ongeveer $9 \%$ van de uitbreidingsvraag van de HRST-beroepen. Uitge- 
drukt in procenten van de werkgelegenheid geven de onderzoeks-beroepen hiermee een uitbreidingsvraag te zien die vergelijkbaar is met andere beroepsgroepen. Wat opvalt is dat de gemiddelde uitbreidingsvraag van de onder-zoeksberoepen $(2,1 \%)$ weliswaar hoger ligt dan het gemiddelde van alle beroepen $(1,2 \%)$, maar iets lager ligt dan het gemiddelde van de HRST-beroepen $(2,2 \%)$.

Tabel 3.1

Uitbreidingsvraag naar HRST-beroepsklasse (in aantal en als percentage van de werkgelegenheid), 2001-2006

\begin{tabular}{lrrc} 
Beroepsklasse & Aantal & $\begin{array}{c}\text { Totaal } \\
\%\end{array}$ & $\begin{array}{c}\text { Gemiddeld } \\
\text { jaarlijks \% }\end{array}$ \\
\hline Pedagogische HRST-beroepen (15) & 12.300 & 4 & 0,7 \\
Culturele HRST-beroepen (6) & 5.600 & 5 & 1,1 \\
Agrarische HRST-beroepen (2) & 2.300 & 12 & 2,3 \\
Technische en industriele HRST-beroepen (12) & 13.900 & 7 & 1,4 \\
Transport HRST-beroepen (1) & 1.300 & 9 & 1,8 \\
Medische en paramedische HRST-beroepen (5) & 13.200 & 6 & 1,1 \\
Economisch-administratieve HRST-beroepen (12) & 138.100 & 18 & 3,3 \\
Informatica HRST-beroepen (3) & 20.800 & 15 & 2,8 \\
Sociaal-culturele HRST-beroepen (4) & 20.500 & 14 & 2,7 \\
Verzorgende en dienstverlenende HRST-beroepen (0) & & - & - \\
Openbare orde- en veiligheids-HRST-beroepen (1) & 800 & 12 & 2,2 \\
& & & 2,2 \\
HRST-beroepen Totaal (61) & 228.900 & 12 & 2,2 \\
Totaal (inclusief elementaire, lagere en middelbare & & & \\
beroepen) & 421.300 & 6 & 1,2
\end{tabular}

Het getal tussen haakjes achter de beroepsklasse geeft het aantal HRST-beroepen binnen de klasse aan.

Bron: ROA

De acht onderzoeksberoepsgroepen vertonen grote verschillen in hun uitbreidingsvraag. Gaven de HRST-beroepsklassen nog onverdeeld groei te zien, voor de onderzoeksberoepsgroepen geldt zelfs dat er één werkgelegenheidskrimp mag verwachten. De materiaalkundigen, een van de vijf onderzoeksberoepsgroepen binnen de Technische en industriële HRST-beroepen, hebben naar verwachting een licht afnemende werkgelegenheid van $-0,1 \%$ gemiddeld per jaar De materiaalkundigen vinden vooral emplooi binnen de bedrijfssector Metaal en elektrotechniek en voor deze bedrijfssector wordt verwacht dat de werkgelegenheid de komende vijf jaar daalt met 9.100 personen (ROA, 2001). Deze daling in de werkgelegenheid komt, afgezien van een kleine krimp voor materiaalkundigen, echter voornamelijk voor rekening van niet-HRST-beroepen binnen de sector. Zo vertonen de elektrotechnici, welke ook veelal binnen de bedrijfssector Metaal en elektrotechniek werkzaam zijn, bijvoorbeeld groei.

De (weg-en water)bouwkundigen zijn de onderzoeksberoepsgroep met verreweg de hoogste uitbreidingsvraag, liefst $7,2 \%$ gemiddeld per jaar. Dit is voornamelijk toe te schrijven aan de gunstige verwachtingen voor de zakelijke dienstverlening, waar ruim $60 \%$ van de (weg- en water)bouwkundigen werkzaam is (ROA, 2001). Verder is ook 
de verwachte uitbreidingsvraag voor economen en sociaal-wetenschappers hoog te noemen.

Tabel 3.2

Uitbreidingsvraag per onderzoeksberoepsgroep (in aantal en als percentage van de werkgelegenheid), 2001-2006

\begin{tabular}{lrrr}
\hline Onderzoeksberoepsgroep & Aantal & $\begin{array}{c}\text { Totaal } \\
\%\end{array}$ & $\begin{array}{c}\text { Gemiddeld } \\
\text { jaarlijks \% }\end{array}$ \\
\hline Landbouwkundigen & 300 & 9 & 1,7 \\
Wiskundigen en natuurwetenschappers & 1.500 & 8 & 1,6 \\
Werktuigbouwkundigen & 700 & 7 & 1,4 \\
(Weg- en water)bouwkundigen & 5.100 & 41 & 7,2 \\
Elektrotechnici & 500 & 6 & 1,3 \\
Materiaalkundigen & -100 & -1 & $-0,1$ \\
Medici en farmaceuten & 3.700 & 5 & 1,0 \\
Economen en sociaal-wetenschappers & 8.700 & 19 & 3,5 \\
Onderzoeksberoepsgroepen Totaal & 20.400 & 11 & 2,1 \\
\hline
\end{tabular}

Bron: ROA

\subsection{Vervangingsvraag}

\section{Vervangingsvraag voor HRST-beroepsklassen}

Naast de baanopeningen die voortkomen uit werkgelegenheidsgroei, is de vervangingsraag een bron van 'nieuwe' arbeidsplaatsen. Vervangingsvraag is het gevolg van (al dan niet tijdelijke) arbeidsmarktuittrede van reeds werkenden. Oorzaken van vervangingsvraag zijn o.a. pensioen, VUT, arbeidsongeschiktheid, en het tijdelijk uittreden van met name vrouwen voor het uitvoeren van kinder- of zorgtaken. Het verlaten van de werkzame beroepsbevolking creëert vraag naar nieuwe arbeidskrachten als uittredende werknemers bij hun vertrek vacante plaatsen achterlaten. In het geval van een constante of groeiende economische activiteit zullen deze vrijgekomen arbeidsplaatsen door nieuwe werknemers opgevuld dienen te worden. Het vertrek van werkenden leidt in tijden van afnemende werkgelegenheid niet tot vervangingsvraag, daar de vacante plaats in dit geval niet zal worden opgevuld.

De omvang van de vervangingsvraag per bedrijf of binnen een beroep wordt bepaald door verschillende factoren. Om te beginnen is de leeftijdsverdeling van het personeel van belang. Een personeelsbestand met relatief veel ouderen mag rekenen op hoge vervangingsvraag vanwege de uitstroom door pensioen- en VUTregelingen. Een jong personeelsbestand reduceert echter niet noodzakelijkerwijs de vervangingsvraag, daar met name startende jongeren, die zich voor het eerst oriënterend aanbieden op de arbeidsmarkt, geneigd zijn veelvuldig van baan te wisselen. Dergelijk gedrag ('job-hopping') houdt vanzelfsprekend niet in dat men zich terugtrekt van de arbeidsmarkt, maar leidt voor het bedrijf waar men werkzaam was wel degelijk tot netto vervangingsvraag. Een tweede factor welke bepalend is voor de 
mate van vervangingsvraag, is het aandeel van vrouwen in het personeelsbestand. De participatie van vrouwen op de arbeidsmarkt is al minder (langdurig) dan dat van mannen, maar ook treden zij vaak tijdelijk uit vanwege zwangerschap en andere daaruit voortvloeiende zorgtaken. De dip in arbeidsmarktparticipatie welke vrouwen rond hun dertigste te zien geven wordt in dit verband wel aangeduid met de term 'kinderdal'. Een derde factor die van invloed is op de mate van vervangingsvraag heeft betrekking op fysieke en psychische belastingsfactoren op het werk. Lichamelijk zwaar werk, werk met veel repeterende bewegingen, hoge werkdruk of een beperkt aantal mogelijkheden om met druk of stress om te gaan, kunnen leiden tot ziekteverzuim en zelfs arbeidsongeschiktheid.

Tabel 3.3

Vervangingsvraag naar HRST-beroepsklasse (in aantal en als percentage van de werkgelegenheid), 2001-2006

\begin{tabular}{|c|c|c|c|}
\hline Beroepsklasse & Aantal & $\begin{array}{c}\text { Totaal } \\
\%\end{array}$ & $\begin{array}{l}\text { Gemiddeld } \\
\text { jaarlijks \% }\end{array}$ \\
\hline Pedagogische HRST-beroepen (15) & 73.700 & 21 & 3,9 \\
\hline Culturele HRST-beroepen (6) & 14.700 & 14 & 2,7 \\
\hline Agrarische HRST-beroepen (2) & 3.100 & 16 & 3,1 \\
\hline Technische en industriële HRST-beroepen (12) & 32.100 & 17 & 3,2 \\
\hline Transport HRST-beroepen (1) & 3.100 & 21 & 3,9 \\
\hline Medische en paramedische HRST-beroepen (5) & 42.300 & 19 & 3,5 \\
\hline Economisch-administratieve HRST-beroepen (12) & 97.600 & 13 & 2,4 \\
\hline Informatica HRST-beroepen (3) & 11.600 & 8 & 1,6 \\
\hline Sociaal-culturele HRST-beroepen (4) & 19.600 & 14 & 2,6 \\
\hline Verzorgende en dienstverlenende HRST-beroepen (0) & - & - & - \\
\hline Openbare orde- en veiligheids- HRST-beroepen (1) & 900 & 13 & 2,5 \\
\hline HRST-beroepen Totaal (61) & 298.600 & 15 & 2,9 \\
\hline $\begin{array}{l}\text { Totaal (inclusief elementaire, lagere en middelba } \\
\text { beroepen) }\end{array}$ & 1.071 .200 & 16 & 3,0 \\
\hline
\end{tabular}

Het getal tussen haakjes achter de beroepsklasse geeft het aantal HRST-beroepen binnen de klasse aan.

Bron: ROA

Tabel 3.3 toont een overzicht van de verwachte vervangingsvraag voor de periode 2001-2006 (in aantallen en percentages) per HRST-beroepsklasse. Daarnaast is een totaal voor de HRST-beroepen opgenomen en een totaal voor de gehele arbeidsmarkt, dat wil zeggen inclusief de niet-HRST-beroepen. Het gemiddelde beeld voor de 61 HRST-beroepsklassen wijkt niet af van het totaalbeeld. De totale vervangingsvraag naar nieuwe arbeidskrachten binnen de HRST-beroepen bedraagt voor de periode 2001-2006 bijna 299.000 personen. Dit komt neer op een gemiddelde jaarlijkse vervangingsvraag ter grootte van $2,9 \%$ van de werkgelegenheid.

Dat het totaalbeeld voor de HRST-beroepen conform het totaal van de gehele arbeidsmarkt is, neemt niet weg dat er binnen de HRST-beroepen verschillen kunnen bestaan. Zo geldt bijvoorbeeld dat de pedagogische HRST-beroepen en de transport HRST-beroepen een relatief hoge vervangingsvraag vertonen. Deze uitkomst kan 
onder andere worden toegeschreven aan een ouder dan gemiddeld personeelsbestand. Daarnaast worden de pedagogische beroepen nogal eens als zwaar beschouwd. Zo geeft men bijvoorbeeld relatief vaak aan last te hebben van lawaai en een hoge werkdruk. Ook de aanzienlijke vervangingsvraag voor de medische en paramedische HRST-beroepen valt op. Hier moet de oorzaak vooral gezocht worden in het grote aandeel vrouwen. Lichamelijk zwaar werk komt weliswaar ook veel voor binnen de medische en paramedische beroepen, maar dit concentreert zich dan voornamelijk in de lagere en middelbare beroepen.

Een uitgesproken lage vervangingsvraag wordt verwacht voor de economischadministratieve HRST-beroepen en de informatica HRST-beroepen. Vooral voor laatstgenoemde HRST-beroepen geldt dat zij een jong en overwegend mannelijk personeelsbestand hebben, wat de uittrede beperkt en daarmee de vervangingsvraag matigt.

\section{Vervangingsvraag voor onderzoeksberoepsgroepen}

Tabel 3.4 toont een overzicht van de verwachte vervangingsvraag voor de periode 2001-2006 per onderzoeksberoepsgroep. Met een totale vervangingsvraag van 28.600 zijn de acht onderzoeksberoepsgroepen verantwoordelijk voor ongeveer $10 \%$ van de vervangingsvraag van de HRST-beroepen. Dit aandeel in de vervangingsvraag komt overeen met het aandeel dat de onderzoeksberoepsgroepen hebben binnen de HRST-beroepen in termen van de werkgelegenheid. Uitgedrukt in procenten van de werkgelegenheid geven de onderzoeksberoepen een gemiddelde vervangingsvraag te zien.

Tabel 3.4

Vervangingsvraag per onderzoeksberoepsgroep (in aantal en als percentage van de werkgelegenheid), 2001-2006

\begin{tabular}{lrcc}
\hline Onderzoeksberoepsgroep & Aantal & $\begin{array}{c}\text { Totaal } \\
\%\end{array}$ & $\begin{array}{c}\text { Gemiddeld } \\
\text { jaarlijks \% }\end{array}$ \\
\hline Landbouwkundigen & 300 & 11 & 2,2 \\
Wiskundigen en natuurwetenschappers & 2.500 & 14 & 2,7 \\
Werktuigbouwkundigen & 1.200 & 12 & 2,4 \\
(Weg- en water)bouwkundigen & 2.000 & 16 & 3,0 \\
Elektrotechnici & 1.500 & 18 & 3,0 \\
Materiaalkundigen & 3.100 & 16 & 3,4 \\
Medici en farmaceuten & 13.100 & 18 & 2,0 \\
Economen en sociaal-wetenschappers & 4.900 & 11 & 2,9 \\
Onderzoeksberoepsgroepen Totaal & 28.600 & 15 & \\
\hline
\end{tabular}

Bron:ROA

De medici en farmaceuten en de elektrotechnici zullen naar verwachting met de hoogste vervangingsvraag te maken krijgen, namelijk 3,4\% gemiddeld per jaar. De oorzaken voor deze hoge vervangingsvraag verschilt voor de twee beroepsgroepen. De beroepsgroep medici en farmaceuten is relatief ouder en minder door mannen gedomineerd dan de beroepsgroep elektrotechnici. Een voor de hand liggende 
oorzaak van hogere gemiddelde leeftijd van medici en farmaceuten, is vanzelfsprekend de lengte van de specialistische opleiding die men vóór beroepsuitoefening voltooid dient te hebben. Opvallend is de lage vervangingsvraag voor economen en sociaal-wetenschappers, slechts $2,0 \%$ gemiddeld per jaar.

\subsection{Baanopeningen}

\section{Baanopeningen voor HRST-beroepsklassen}

Op basis van de uitbreidingsvraag en vervangingsvraag kunnen de verwachte baanopeningen voor de periode 2001-2006 afgeleid worden. ${ }^{12}$ Tabel 3.5 toont een overzicht van de verwachte baanopeningen per HRST-beroepsklasse. Daarnaast is een totaal voor de HRST-beroepen opgenomen en een totaal voor de gehele arbeidsmarkt, dat wil zeggen inclusief de niet-HRST-beroepen. Opgemerkt zij dat, vanwege onderliggende krimp, de baanopeningen naar HRST-beroepsklasse niet precies overeen zullen komen met de gegevens van tabellen 3.1 en 3.3. Het gemiddelde beeld voor de 61 HRST-beroepen wijkt vanwege de afwijkende uitbreidingsvraag licht af van het totaalbeeld. De totale vraag naar nieuwe arbeidskrachten binnen de HRST-beroepen bedraagt voor de periode 2001-2006 ca. 540.000 personen. Dit komt neer op een gemiddeld jaarlijkse percentage baanopeningen van $5,0 \%$ van de werkgelegenheid.

Met uitzondering van de culturele HRST-beroepen geldt voor alle HRST-beroepsklassen dat het percentage baanopeningen hoger ligt dan voor de arbeidsmarkt als geheel. Aangezien de vervangingsvraag binnen de HRST-beroepen vergelijkbaar was met de vervangingsvraag over alle beroepen, inclusief de elementaire, lagere en middelbare beroepen, moeten deze verschillen worden toegeschreven aan de hogere uitbreidingsvraag voor HRST-beroepen. Vervangingsvraag is ook voor de meeste HRST-beroepen de belangrijkste bron van vraag naar arbeidskrachten, maar het hogere aantal baanopeningen hebben de HRST-beroepen duidelijk te danken aan de hogere uitbreidingsvraag.

Voor economisch-administratieve HRST-beroepen bestaat $60 \%$ van de baanopeningen uit uitbreidingsvraag. Ook voor de informatica HRST-beroepen speelt de uitbreidingsvraag een relatief grote rol: de gemiddelde leeftijd in deze beroepsklasse is laag, waardoor de vervangingsvraag klein is. De vervangingsvraag speelt daarentegen een grote rol in beroepsklassen met een ouder personeelsbestand en achterblijvende werkgelegenheidsgroei, zoals de transport HRST-beroepen, of beroepsklassen met relatief zware arbeidsomstandigheden en een groot aandeel

12. De totale vraag naar (nieuwe) arbeidskrachten wordt gevormd door de som van de uitbreidingsvraag, mits deze positief is, en de vervangingsvraag. Deze totale vraag, of baanopeningen, heeft vooral betrekking op nieuwkomers op de arbeidsmarkt, de schoolverlaters. De reden voor het niet meenemen van een eventuele negatieve werkgelegenheidsontwikkeling bij het bepalen van de totale vraag is dat wordt verondersteld dat een werkgelegenheidskrimp vooral gevoeld zal worden door oudere, reeds werkende arbeidskrachten en in mindere mate door nieuwkomers op de arbeidsmarkt. 
vrouwen, zoals de medisch en paramedische HRST-beroepen, is de vervangingsvraag verantwoordelijk voor de meerderheid van de nieuwe arbeidsplaatsen.

Tabel 3.5

Baanopeningen naar HRST-beroepsklasse (in aantal en als percentage van de werkgelegenheid), 2001-2006

\begin{tabular}{|c|c|c|c|}
\hline Beroepsklasse & Aantal & $\begin{array}{l}\text { Totaal } \\
\%\end{array}$ & $\begin{array}{l}\text { Gemiddeld } \\
\text { jaarlijks \% }\end{array}$ \\
\hline Pedagogische HRST- beroepen (15) & 92.900 & 27 & 4,9 \\
\hline Culturele HRST-beroepen (6) & 21.400 & 20 & 3,8 \\
\hline Agrarische HRST-beroepen (2) & 5.400 & 28 & 5,1 \\
\hline Technische en industriële HRST-beroepen (12) & 48.500 & 26 & 4,7 \\
\hline Transport HRST-beroepen (1) & 4.400 & 30 & 5,4 \\
\hline Medische en paramedische HRST-beroepen (5) & 56.400 & 25 & 4,5 \\
\hline Economisch-administratieve HRST-beroepen (12) & 236.000 & 30 & 5,5 \\
\hline Informatica HRST-beroepen (3) & 33.500 & 23 & 4,3 \\
\hline Sociaal-culturele HRST-beroepen (4) & 40.100 & 28 & 5,0 \\
\hline Verzorgende en dienstverlenende HRST-beroepen (0) & & - & - \\
\hline Openbare orde- en veiligheids- HRST-beroepen (1) & 1.700 & 25 & 4,6 \\
\hline HRST-beroepen Totaal (61) & 540.400 & 27 & 5,0 \\
\hline $\begin{array}{l}\text { Totaal (inclusief elementaire, lagere en middelb } \\
\text { beroepen) }\end{array}$ & 1.525 .300 & 22 & 4,1 \\
\hline
\end{tabular}

Het getal tussen haakjes achter de beroepsklasse geeft het aantal HRST-beroepen binnen de klasse aan.

Het percentage baanopeningen is op dit hogere aggregatieniveau vaak niet gelijk aan de som van de (niet-negatieve) uitbreidingsvraag en de vervangingsvraag uit tabellen 1 en 3 . De verklaring hiervoor ligt in het feit dat de baanopeningen eerst per beroep worden bepaald (bijvoorbeeld systeemanalist) en pas daarna worden opgeteld naar beroepsklasse (bijvoorbeeld de informaticaberoepen).

Bron: ROA

Baanopeningen voor onderzoeksberoepsgroepen

Tabel 3.6 toont een overzicht van de verwachte baanopeningen voor de periode 2001-2006 (in aantallen en percentages) per onderzoeksberoepsgroep. Het totale aantal baanopeningen van 49.100 voor de acht onderzoeksberoepsgroepen in deze periode weerspiegelt een relatieve vraag van ongeveer $4,8 \%$ gemiddeld per jaar. Dit ligt weliswaar hoger dan het gemiddelde percentage baanopeningen over alle beroepen $(4,1 \%)$ inclusief de elementaire, lagere en middelbare beroepen, maar het is lager dan het gemiddelde voor de HRST-beroepen $(5,0 \%)$.

De materiaalkundigen, de werktuigbouwkundigen en de landbouwkundigen vertonen een voor onderzoeksberoepsgroepen laag aantal baanopeningen: minder dan 4\% per jaar. Voor de materiaalkundigen is dit te wijten aan de negatieve uitbreidingsvraag, voor de andere twee onderzoeksberoepsgroepen is er sprake van een relatief lage vervangingsvraag. 
Tabel 3.6

Baanopeningen naar onderzoeksberoepsgroep (in aantal en als percentage van de werkgelegenheid), 2001-2006

\begin{tabular}{lrrr}
\hline Onderzoeksberoepsgroep & Aantal & $\begin{array}{c}\text { Totaal } \\
\%\end{array}$ & $\begin{array}{c}\text { Gemiddeld. } \\
\text { jaarlijks \% }\end{array}$ \\
\hline Landbouwkundigen & 600 & 20 & 3,8 \\
Wiskundigen en natuurwetenschappers & 4.000 & 22 & 4,1 \\
Werktuigbouwkundigen & 1.800 & 20 & 3,7 \\
(Weg- en water)bouwkundigen & 7.100 & 57 & 9,5 \\
Elektrotechnici & 2.000 & 24 & 4,5 \\
Materiaalkundigen & 3.100 & 16 & 3,0 \\
Medici en farmaceuten & 16.800 & 24 & 4,3 \\
Economen en sociaal-wetenschappers & 13.600 & 29 & 5,3 \\
Onderzoeksberoepsgroepen Totaal & 49.100 & 26 & 4,8 \\
& & & \\
\hline
\end{tabular}

Bron: ROA

\subsection{Arbeidsmarktinstroom}

\section{Arbeidsmarktinstroom van afgestudeerden van HRST-opleidingen}

Om een goed beeld te krijgen van de toekomstige situatie op de arbeidsmarkt, dienen naast de ontwikkelingen in de vraag naar arbeid ook de ontwikkelingen van het arbeidsaanbod in kaart te worden gebracht. Binnen dit arbeidsaanbod kunnen een drietal componenten worden onderscheiden: de schoolverlaters, de werklozen en de stille reserve. Voor het bepalen van de toekomstige arbeidsmarktsituatie wordt aangenomen dat schoolverlaters en kortdurig werklozen met elkaar concurreren terwijl langdurig werklozen en de stille reserve een zwakkere positie hebben. Vandaar dat de twee laatste groepen buiten beschouwing blijven bij het maken van prognoses van de positie van schoolverlaters op de arbeidsmarkt.

De grootste en belangrijkste component van het arbeidsaanbod bestaat uit de voor de komende vijf jaar verwachte arbeidsmarktinstroom van schoolverlaters. Hierbij kan een onderscheid worden gemaakt tussen schoolverlaters die vanuit het initiële (dag)onderwijs de arbeidsmarkt instromen en reeds werkenden die door middel van niet-initieel (avond)onderwijs hun kwalificatieprofiel dusdanig hebben veranderd dat zij vanwege hun gewijzigde opleidingsachtergrond als nieuw arbeidsaanbod beschouwd kunnen worden. Daarbij kan gedacht worden aan opleidingen die het initiële opleidingsniveau verhogen of opleidingen die de initiële opleidingsrichting wijzigen.

Tabel 3.7 toont de verwachte instroom van afgestudeerden van de HRSTopleidingen. Ten opzichte van het gemiddelde jaarlijkse percentage afgestudeerden dat de arbeidsmarkt instroomt van alle opleidingscategorieën (HRST en niet-HRST), zijn er maar weinig HRST-opleidingscategorieën waarvoor een hogere instroom van afgestudeerden wordt verwacht. Het gaat hierbij om $\mathrm{HBO}$ economie en WO economie. Daartegenover worden er weinig afgestudeerden met een medische WOopleiding of een landbouw en techniek opleiding op HBO- en WO-niveau verwacht. 
Het tekort aan personen met een techniekopleiding zal daarom in de komende jaren waarschijnlijk alleen maar toenemen.

Tabel 3.7

Verwachte instroom van afgestudeerden naar HRST-opleidingscategorie, 2001-2006

\begin{tabular}{lrrr}
\hline Opleidingscategorie & Totaal & $\begin{array}{c}\text { Totaal } \\
\%\end{array}$ & $\begin{array}{c}\text { Gemiddeld } \\
\text { jaarlijks \% }\end{array}$ \\
\hline HBO landbouw en techniek (11) & 50.500 & 17 & 3,2 \\
HBO economie (6) & 99.000 & 32 & 5,7 \\
HBO onderwijs en sociaal-cultureel (13) & 104.000 & 19 & 3,5 \\
HBO paramedisch (4) & 30.000 & 23 & 4,2 \\
WO landbouw en techniek (7) & 24.500 & 17 & 3,3 \\
WO economie (4) & 51.000 & 26 & 4,7 \\
WO letteren en sociaal-cultureel (4) & 40.000 & 22 & 4,1 \\
WO medisch (4) & 9.500 & 14 & 2,7 \\
Totaal (incl. niet-HRST-opleidingen) & 1.685 .800 & 24 & 4,4 \\
\hline
\end{tabular}

Tussen haakjes het aantal opleidingstypen binnen de opleidingscategorie.

\section{Bron: ROA}

De opleidingscategorieën waarvan de instroom in bovenstaande tabel staat weergegeven, bestaan uit verschillende opleidingstypen. De arbeidsmarktinstroom kan binnen deze opleidingscategorieën voor de onderliggende opleidingstypen aanzienlijk verschillen. Binnen $H B O$ economie zijn vooral $H B O$ toerisme en recreatie en $H B O$ bedrijfskunde erg in trek. Binnen de opleidingscategorie WO economie laat WO accountancy en belastingen een lage instroom zien. Meer in trek binnen deze opleidingscategorie zijn WO bedrijfskunde en WO rechten en bestuurskunde. Ten slotte is de verwachte arbeidsmarktinstroom van WO medisch laag, hetgeen te wijten is aan de numerus fixus voor deze opleidingen.

\section{Arbeidsmarktinstroom van afgestudeerden met WO-opleidingen}

De bovengenoemde variatie in de instroom van schoolverlaters binnen een opleidingscategorie komt met name naar voren in tabel 3.8. Hierin worden de prognoses voor afgestudeerden uit het WO naar opleidingstype, dat wil zeggen op het laagste ROA-aggregatieniveau, getoond. Onderzoekers worden vooral gerecruteerd uit het WO. Afgestudeerden uit het WO zullen niet allemaal als onderzoeker gaan werken, sommigen zullen in een ander HRST-beroep terechtkomen of zelfs een niet-HRST-beroep. In het laatste geval is er sprake van onbenut HRSTpotentieel.

Uit tabel 3.8 blijkt dat het instroompercentage van de technische opleidingen, bijvoorbeeld WO elektrotechniek (9\%) ver achter blijft bij het gemiddelde instroompercentage voor alle opleidingstypen (zowel HBO-WO als MBO en lager) (24\%), terwijl bijvoorbeeld WO bedrijfskunde (35\%) daar ver boven ligt. Een dergelijke ontwikkeling van de arbeidsmarktinstroom kan een negatieve invloed op de economie hebben. Uit onderzoek van Murphy, Shleifer \& Vishny (1991) blijkt immers dat landen met een groot aantal technisch afgestudeerden sneller groeien 
dan landen met een groot aantal afgestudeerden in de rechten. Talentvolle jongeren die kiezen voor studierichtingen waarin ze het meest verwachten te verdienen, zoals rechten ${ }^{13}$, komen in beroepen terecht die volgens de auteurs vooral gericht op 'rentseeking' (hetgeen slecht is voor economische groei), terwijl de vaak minder betaalde technici meer bezig zijn met innovatie en ondernemerschap (hetgeen goed is voor economische groei).

Tabel 3.8

Verwachte instroom van afgestudeerden naar WO-opleidingstype, 2001-2006

\begin{tabular}{lrrr}
\hline Opleidingstype & Totaal & $\begin{array}{c}\text { Totaal } \\
\%\end{array}$ & $\begin{array}{c}\text { Gemiddeld } \\
\text { jaarlijks \% }\end{array}$ \\
& & & \\
WO letteren & 13.800 & 24 & 4,4 \\
WO theologie & 700 & 8 & 1,5 \\
WO landbouw en milieukunde & 3.600 & 24 & 4,4 \\
WO wiskunde en natuurwetenschappen & 11.500 & 16 & 3,1 \\
WO bouwkunde & 2.800 & 23 & 4,2 \\
WO civiele techniek & 1.000 & 15 & 2,8 \\
WO werktuigbouwkunde & 2.600 & 19 & 3,6 \\
WO elektrotechniek & 1.100 & 9 & 1,8 \\
WO informatica en bestuurlijke & & & 3,3 \\
informatiekunde & 1.900 & 18 & 2,8 \\
WO (dier)geneeskunde & 7.500 & 15 & 2,0 \\
WO tandheelkunde & 600 & 10 & 2,7 \\
WO farmacie en medische biologie & 1.300 & 14 & 4,7 \\
WO econom(etr)ie & 15.300 & 26 & 6,1 \\
WO bedrijfskunde & 12.200 & 35 & 2,8 \\
WO accountancy en belastingen & 3.700 & 15 & 4,7 \\
WO rechten en bestuurskunde & 20.000 & 26 & 4,2 \\
WO sociale wetenschappen & 23.800 & 23 & 4,9 \\
WO kunstwetenschappen & 1.600 & 27 & 4,4 \\
& & & \\
Totaal (incl. niet-WO- opleidingstypen) & 1.685 .800 & 24 & \\
& & &
\end{tabular}

Bron: ROA

\subsection{Verwachte knelpunten in de personeelsvoorziening naar beroep}

\section{Knelpunten in de personeelsvoorziening voor HRST-beroepsklassen}

Het confronteren van de totale vraag en het totale aanbod geeft een indicatie van de te verwachten knelpunten in de personeelsvoorziening voor werkgevers. Om inzicht te verschaffen in de specifieke wervingsproblematiek in de verschillende beroepsgroepen, wordt gebruik gemaakt van de Indicator Toekomstige Knelpunten in de personeelsvoorziening naar Beroep (ITKB). De ITKB geeft aan in welke mate het voor werkgevers mogelijk is om de gewenste personeelssamenstelling te realiseren, bij de voorspelde vraag-aanbod-verhoudingen. De ITKB heeft een waarde tussen de 0 en de 1 , en naarmate de waarde van de indicator lager is, des te groter zijn de knelpunten in de personeelsvoorziening voor de desbetreffende beroepsgroep.

13. En in Nederland ook medicijnen (Oosterbeek \& Webbink, 1997). 
Tabel 3.9

Indicator Toekomstige Knelpunten in de personeelsvoorziening naar Beroep (ITKB), naar HRST-beroepsklasse, 2001-2006

\begin{tabular}{lcl} 
Beroepsklasse $^{\text {a }}$ & ITKB $^{\mathrm{b}}$ & Typering $^{\mathrm{b}}$ \\
\hline Pedagogische HRST-beroepen (15) & & \\
Culturele HRST-beroepen (6) & 0,86 & zeer groot \\
Agrarische HRST-beroepen (2) & 0,91 & groot \\
Technische en industriële HRST-beroepen (12) & 0,93 & groot \\
Transport HRST-beroepen (1) & 0,91 & groot \\
Medische en paramedische HRST-beroepen (5) & 0,91 & groot \\
Economisch-administratieve HRST-beroepen (12) & 0,88 & zeer groot \\
Informatica HRST-beroepen (3) & 0,92 & groot \\
Sociaal-culturele HRST-beroepen (4) & 0,87 & zeer groot \\
Verzorgende en dienstverlenende HRSTberoepen (0) & 0,91 & groot \\
Openbare orde- en veiligheids- HRST-beroepen (1) & - & - \\
& 0,94 & groot \\
HRST-beroepen Totaal (61) & 0,90 & groot
\end{tabular}

${ }^{a}$ Het getal tussen haakjes achter de beroepsklasse geeft het aantal HRST-beroepen binnen de klasse aan.

${ }^{b}$ De ITKB per HRST-beroepsklasse is een gewogen gemiddelde van de ITKB naar de HRSTberoepen binnen de klasse, waarbij de weging is gebaseerd op het aantal werkenden in het beroep.

${ }^{\mathrm{C}}$ Typeringen gebaseerd op de verdeling de ITKB op het niveau van de beroepen (d.w.z. niet op het niveau van beroepsklasse bepaald).

Bron: ROA

Tabel 3.9 geeft een overzicht van de (geconstrueerde) ITKB voor de HRSTberoepsklassen. De ITKB is in eerste instantie op het meest gedetailleerde aggregatieniveau, dat van beroepsgroep, bepaald en vervolgens gewogen naar aantallen werkenden. De typering, welke aangeeft hoe de waarde van de ITKB zich verhoudt tot de ITKB voor het geheel van de arbeidsmarkt, is tevens gebaseerd op grenzen vastgesteld op het niveau van beroepsgroep. Tabel 3.9 geeft aan dat werkgevers in de HRST-beroepsklassen zonder uitzondering te maken zullen krijgen met grote tot zeer grote knelpunten in de personeelsvoorziening. In alle gevallen zal het aanbod van nieuwe arbeidskrachten (afgestudeerden) in 2006 te kort schieten om aan de vraag te kunnen voldoen. De problemen lijken het grootst te gaan worden voor de pedagogische HRST-beroepen, de informatica HRST-beroepen en de medische en paramedische HRST-beroepen.

Tabel 3.10 geeft per HRST-beroepsklasse aan hoeveel van de werkenden binnen de klasse in de periode tot 2006 met een bepaalde ITKB-typering te maken zullen gaan hebben. Het contrast tussen de 61 HRST-beroepsklassen en rest is zeer groot. De grote en zeer grote knelpunten zijn zwaar oververtegenwoordigd. Andermaal is duidelijk dat beroepen met (vrijwel) geen knelpunten voornamelijk, zoniet uitsluitend, gezocht moeten worden binnen de niet-HRST-beroepen. Alleen de culturele en de agrarische HRST-beroepsklassen geven voor tenminste $15 \%$ van de werkenden slechts 'enige' toekomstige knelpunten in de personeelsvoorziening te zien. 
Tabel 3.10

Percentage werkenden naar de typering van de verwachte knelpunten in de personeelsvoorziening naar HRST-beroepsklasse, 2001-2006

\begin{tabular}{lrrr}
\hline Beroepsklasse & $\begin{array}{r}\text { (vrijwel) geen } \\
\text { knelpunten }\end{array}$ & $\begin{array}{r}\text { enige } \\
\text { knelpunten }\end{array}$ & $\begin{array}{r}\text { (zeer) grote } \\
\text { knelpunten }\end{array}$ \\
\hline Pedagogische HRST-beroepen (15) & 0 & 0 & 100 \\
Culturele HRST-beroepen (6) & 0 & 17 & 83 \\
Agrarische HRST-beroepen (2) & 0 & 15 & 85 \\
Technische en industriële HRST-beroepen (12) & 6 & 0 & 94 \\
Transport HRST-beroepen (1) & 0 & 0 & 100 \\
Medische en paramedische HRST-beroepen (5) & 0 & 3 & 97 \\
Economisch-administratieve HRST-beroepen (12) & 0 & 8 & 92 \\
Informatica HRST-beroepen (3) & 0 & 0 & 100 \\
Sociaal-culturele HRST-beroepen (4) & 0 & 0 & 100 \\
Verzorgende en dienstverlenende HRST-beroepen (0) & - & - & - \\
Openbare orde- en veiligheids- HRST-beroepen (1) & 0 & 0 & 100 \\
HRST-beroepen Totaal (61) & 1 & 5 & 95 \\
Total (inclusief elementaire, lagere en middelbare & 35 & 10 & 55 \\
beroepen) & & & \\
\end{tabular}

\section{Bron: ROA}

Knelpunten in de personeelsvoorziening voor onderzoeksberoepsgroepen

Tabel 3.11 toont de ITKB voor de onderzoeksberoepsgroepen. Alleen de werkgevers van landbouwkundigen lijken zich aan het negatieve toekomstbeeld te onttrekken: met een ITKB van 0,95 hebben zij 'slechts' enige knelpunten in de personeelsvoorziening, vooral vanwege de lage vervangingsvraag.

Tabel 3.11

Indicator Toekomstige Knelpunten in de personeelsvoorziening naar Beroep (ITKB), naar onderzoeksberoepsgroep, 2001-2006

\begin{tabular}{lll}
\hline Onderzoeksberoepsgroep & ITKB & Typering \\
\hline & & \\
Landbouwkundigen & 0,95 & enige \\
Wiskundigen en natuurwetenschappers & 0,93 & groot \\
Werktuigbouwkundigen & 0,92 & groot \\
(Weg- en water)bouwkundigen & 0,86 & zeer groot \\
Elektrotechnici & 0,83 & zeer groot \\
Materiaalkundigen & 0,92 & groot \\
Medici en farmaceuten & 0,94 & groot \\
Economen en sociaal-wetenschappers & 0,88 & zeer groot \\
& & \\
Onderzoeksberoepsgroepen Totaal* & 0,91 & groot
\end{tabular}

* De ITKB voor het totaal van de acht onderzoeksberoepsgroepen is een gewogen gemiddelde van de ITKB van de onderzoeksberoepsgroepen, waarbij de weging is gebaseerd op het aantal werkenden in de beroepsgroep.

Bron: ROA 
Verder gelden voor de andere onderzoeksberoepsgroepen onverdeeld grote tot zeer grote toekomstige knelpunten. Dit betekent dat de meeste werkgevers van R\&Dpersoneel ook de komende jaren tot 2006 sterke concurrentie op de arbeidsmarkt zullen ondervinden, niet alleen van andere R\&D-instellingen en -afdelingen, maar ook van werkgevers die hoogopgeleiden nodig hebben om de baanopeningen voor andere HRST-beroepen te vullen. 


\section{Kenniswerkers in de publieke en private sector}

\subsection{Inleiding}

In de voorgaande twee hoofdstukken hebben we de recente en verwachte ontwikkelingen op de arbeidsmarkt voor kenniswerkers bekeken vanuit het perspectief van opleidingsachtergronden en beroepsuitoefening. In dit hoofdstuk beschouwen we de arbeidsmarkt voor kenniswerkers vanuit het oogpunt van de bedrijfssectoren waarin R\&D-werkers actief zijn. Uit tabel 4.1 die gebaseerd is op de R\&D-enquête van het CBS blijkt dat er ongeveer evenveel onderzoekers werkzaam zijn in de publieke als in de particuliere sector. In het bedrijfsleven werken de meeste onderzoekers in de industrie. De (semi-)overheidsinstellingen hebben ongeveer evenveel onderzoekers in dienst als de universiteiten.

Tabel 4.1

R\&D-personeel naar bedrijfssector, 1999

\begin{tabular}{lrr}
\hline & $\begin{array}{r}\text { Totaal aantal } \\
\text { R\&D-personeel }\end{array}$ & $\begin{array}{r}\text { Waarvan: aantal } \\
\text { onderzoekers }\end{array}$ \\
\hline Totaal bedrijfsleven & 61.377 & $\mathbf{2 4 . 6 3 5}$ \\
Industrie & 43.079 & 15.117 \\
Diensten & 14.139 & 7.757 \\
Overig bedrijfsleven & 4.159 & 1.762 \\
Totaal researchinstellingen & 19.654 & $\mathbf{9 . 4 1 8}$ \\
(Semi-) overheidsinstellingen & 18.360 & 8.729 \\
Particuliere non-profit-instellingen & 1.294 & 689 \\
Totaal universiteiten* & & $\mathbf{1 2 . 7 4 0}$ \\
Totaal & $\mathbf{2 4 . 3 0 2}$ & $\mathbf{4 6 . 7 9 3}$ \\
\hline
\end{tabular}

* arbeidsjaren.

Bron: CBS, Kennis en economie 2001, Tabel 3.2.2., 3.2.3, A.3.1.4, A.4.1.10

In tabel 4.2 wordt ingezoomd op R\&D-personeel dat werkzaam is in het bedrijfsleven. De meeste onderzoekers in de industrie zijn werkzaam in bedrijfstakken die tot de metalektro of de chemie gerekend kunnen worden. Daarnaast werken ook veel onderzoekers in de voedings- en genotmiddelenindustrie. In de dienstensector wordt R\&D vooral verricht in architecten- en ingenieurbureau's, computerservicebureau's en de groothandel. In het overig bedrijfsleven werkt veel R\&D-personeel in de landbouw \& visserij, maar het gaat hierbij vooral om technisch assistenten en ander ondersteunend personeel en in mindere mate om wetenschappelijk onderzoekers. 
Tabel 4.2

R\&D-personeel in het bedrijfsleven naar bedrijfssector, 1999

\begin{tabular}{ccc}
\hline Bedrijfssector & Totaal aantal & Waarvan: \\
R\&D-personeel & aantal onderzoekers
\end{tabular}

\begin{tabular}{lrr}
\hline & & \\
Totaal bedrijfsleven & $\mathbf{6 1 . 3 7 7}$ & $\mathbf{2 4 . 6 3 5}$ \\
Totaal industrie & $\mathbf{4 3 . 0 7 9}$ & $\mathbf{1 5 . 1 1 7}$ \\
Voedings- en genotmiddelenindustrie & 4.017 & 1.713 \\
Textiel- en lederindustrie & 409 & 145 \\
Papierindustrie & 532 & 209 \\
Uitgeverijen en drukkerijen & 681 & 234 \\
Aardolie-industrie & 616 & $112^{*}$ \\
Chemische basisproductenindsutrie & 2.264 & 820 \\
Farmaceutische industrie & 3.545 & $979^{*}$ \\
Ov. Chemische eindproductenindustrie & 3.390 & 1.238 \\
Rubber- en kunststofindustrie & 1.409 & 493 \\
Basismetaalindustrie & 812 & 302 \\
Metaalproductenindustrie & 2.029 & 824 \\
Machine-industrie & 5.656 & 1.801 \\
Elektrotechnische industrie & 13.181 & 4.890 \\
Transportmiddelenindustrie & 3.583 & 735 \\
Overige industrie & 956 & 327 \\
Totaal diensten & 14.139 & 7.757 \\
Groothandel & 3.348 & 1.367 \\
Detailhandel en reparatie & 585 & 148 \\
Vervoer \& communicatie & 1.247 & 914 \\
Financiële instellingen & 1.122 & 652 \\
Computerservicebureau's & 2.777 & 1.665 \\
Researchondernemingen & 448 & 171 \\
Juridische en economische adviesdiensten & 557 & 176 \\
Architecten en ingenieurbureau's & 3.193 & 2.095 \\
Verhuur \& rest ov. Zakelijke dienstverlening & 650 & 443 \\
Milieudienstverlening & 213 & 125 \\
Totaal overig bedrijfsleven & 4.159 & 1.762 \\
Landbouw, bosbouw \& visserij & 1.442 & 285 \\
Delfstoffenwinning & 990 & 574 \\
Elektriciteit, gas \& water & 456 & 127 \\
Bouwnijverheid & 1.270 & 776 \\
& & \\
\hline Gegevens voor & &
\end{tabular}

* Gegevens voor 1998, CBS, Kennis en economie 2000, Tabel A.4.2.9.

Bron: CBS, Kennis en economie 2001, Tabel A.4.1.10

\subsection{Knelpunten in de personeelsvoorziening van bedrijfssectoren}

In hoofdstuk 2 en 3 werden knelpunten in de personeelsvoorziening beschouwd vanuit het perspectief van opleidingsachtergronden en beroepen. Hiermee werd een beeld verkregen van de huidige en verwachte schaarste aan mensen met een specifieke opleidingsachtergrond of een specifiek beroep waarmee de Nederlandse economie als geheel te maken heeft of krijgt. In dit hoofdstuk bekijken we de knelpunten op de arbeidsmarkt voor kenniswerkers vanuit het perspectief van de verschillende sectoren van de economie. Uit tabel 4.3 die gebaseerd is op de Innovatie-enquête van het CBS blijkt dat een op de vijf innovatieve bedrijven in de periode 1996-1998 te kampen had met tekorten aan gekwalificeerd personeel. Hierbij was er weinig verschil te bespeuren tussen de industrie als geheel en de dienstensector als geheel. Echter op een lager aggregatieniveau zijn de verschillen 
in ervaren knelpunten in de personeelsvoorziening aanzienlijk. In de industrie treden de kwalitatieve personeelstekorten vooral op in de elektrotechnische industrie, de overige chemische eindproductenindustrie, de rubber- en kunststofindustrie, de farmaceutische industrie en de machine-industrie. In de dienstensector gaat het vooral om computerservicebureau's, financiële instellingen, architecten- en ingenieurbureau's en de groothandel. In het overige bedrijfsleven is er alleen bij elektriciteit, gas \& water sprake van bovengemiddelde personeelstekorten. Overigens bevat de Innovatie-enquête geen informatie over de omvang van de personeelstekorten in aantallen werknemers.

Tabel 4.3

Knelpunten in de personeelsvoorziening in het bedrijfsleven naar bedrijfsklasse, 1996-1998

Totaal bedrijfsleven

Totaal industrie

Voedings- en genotmiddelenindustrie

Textiel- en lederindustrie

Papierindustrie

Uitgeverijen en drukkerijen

Aardolie-industrie

Chemische basisproductenindsutrie

Farmaceutische industrie

Ov. Chemische eindproductenindustrie $\quad 29$

Rubber- en kunststofindustrie $\quad 28$

Basismetaalindustrie 19

Metaalproductenindustrie $\quad 17$

Machine-industrie $\quad 24$

Elektrotechnische industrie $\quad 34$

Transportmiddelenindustrie $\quad 21$

Overige industrie 13

Totaal diensten 19

Groothandel 22

Detailhandel en reparatie $\quad 9$

Horeca \& autohandel 11

Vervoer \& communicatie $\quad 17$

Financiële instellingen $\quad 30$

Computerservicebureau's 48

Juridische en economische adviesdiensten 21

Architecten en ingenieurbureau's $\quad 25$

Verhuur \& rest ov. Zakelijke dienstverlening 16

Milieudienstverlening 10

Overige dienstverlening 14

Totaal overig bedrijfsleven 12

Landbouw, bosbouw \& visserij 11

Delfstoffenwinning 6

Elektriciteit, gas \& water $\quad 21$

Bouwnijverheid 12

Bron: CBS, Kennis en economie 2000, tabel A.6.2.3 


\subsection{Crowding out op de arbeidsmarkt voor kenniswerkers ${ }^{14}$}

Tekorten aan gekwalificeerd R\&D-personeel komen voor in alle sectoren van het Nederlands bedrijfsleven, zoals bleek in de voorgaande paragraaf. Voor het uitvoeren van R\&D-activiteiten is slechts een beperkte groep kenniswerkers beschikbaar. Dit betekent dat een intensivering van R\&D-activiteiten in bepaalde sectoren van de Nederlandse economie via de arbeidsmarkt voor kenniswerkers ook gevolgen heeft voor de overige sectoren. Vanwege de arbeidsmobiliteit tussen sectoren, zal een loonstijging in de ene sector kenniswerkers aantrekken uit de andere sector. Om de uitstroom van kenniswerkers te stoppen zal dan ook de andere sector de lonen moeten verhogen. Een toename van de R\&D-uitgaven in een sector verhoogt derhalve het aantal kenniswerkers en de lonen in de eigen sector, maar verlaagt het aantal kenniswerkers en verhoogt de lonen in andere sectoren (zie tabel 4.4). Veranderingen in de sectorale allocatie van kenniswerkers kan gevolgen hebben voor de lange-termijn-groeivoet van de economie als niet alle sectoren dezelfde bijdrage aan deze groeivoet leveren. Voor innovatiebeleid is het van belang rekening te houden met deze crowding-out-effecten op de arbeidsmarkt voor kenniswerkers. In de eerste plaats kan de overheid randvoorwaarden scheppen waardoor crowdingout-effecten zoveel mogelijk kunnen worden opgevangen. In de tweede plaats kunnen bestaande beleidsmaatregelen zelf ook onbedoeld crowding-out-effecten versterken.

Tabel 4.4

Effecten van sectorale R\&D-uitgaven op arbeidsmarkt voor kenniswerkers

\begin{tabular}{ccc}
\hline $\begin{array}{c}\text { Eigen sector } \\
\text { Andere sectoren }\end{array}$ & $\begin{array}{c}\text { toename } \\
\text { afname }\end{array}$ & toename \\
toename
\end{tabular}

Hierbij gaat het niet alleen om afwegingen tussen verschillende sectoren van het bedrijfsleven, maar ook tussen het bedrijfsleven enerzijds en overheidsinstellingen en universiteiten anderzijds. In het bedrijfsleven ligt de nadruk op toegepast onderzoek, terwijl in overheidsinstellingen en vooral universiteiten meer aan fundamenteel onderzoek gedaan wordt. Het stimuleren van R\&D in het bedrijfsleven zou dan een negatief effect kunnen hebben op de omvang van het fundamenteel onderzoek. Met name op de lange termijn kan dit nadelige effecten hebben. Anderzijds kan het stimuleren van R\&D in overheidsinstellingen en universiteiten leiden tot zowel het onttrekken van werknemers aan het bedrijfsleven als het opdrijven van de lonen van kenniswerkers in het bedrijfsleven.

De omvang van de crowding-out-effecten hangt af van de mate van similariteit van de opleidingsachtergronden van kenniswerkers in de verschillende sectoren, als-

14. De crowding-out-analyse in dit hoofdstuk is gebaseerd op het binnenkort te verschijnen ROA-rapport Crowding out in the Dutch labour market for R\&D workers (ROA, 2002). 
mede de mogelijkheden om Nederlandse kenniswerkers te vervangen door buitenlandse. Naarmate de gevraagde opleidingsachtergronden in twee sectoren meer op elkaar lijken, zullen de crowding-out-effecten een grotere omvang hebben. Uit onderzoek voor de Verenigde Staten blijkt dat federale R\&D-uitgaven een opwaarts effect hebben op de lonen van ingenieurs vliegtuigbouwkunde, werktuigbouwkunde, materiaalkunde en electrotechniek. Dit zijn de typische defensie-industrie beroepen, waar tenslotte het merendeel van de federale R\&Duitgaven aan wordt gespendeerd (Goolsbee, 1998). Hiermee wordt niet alleen de R\&D in de sector waarin de speerpunt-technologie wordt ontwikkeld duurder, maar ook de R\&D in enkele andere sectoren. Bovendien worden kenniswerkers aan die andere sectoren onttrokken. De Amerikaanse overheid staat daarmee voor een trade-off tussen het direct stimuleren van de ene sector en het indirect afremmen van andere sectoren. In geval van crowding-out-effecten tussen bedrijfsleven en publieke sfeer kan er een dempend effect uitgaan van de heterogeniteit van preferenties van werknemers: de voorkeur voor het verrichten van fundamenteel onderzoek boven toegepast onderzoek kan ertoe leiden dat sommige mensen bereid zijn een aanzienlijk loonverschil te accepteren. Uit een onderzoek onder postdoctorale biologen in de Verenigde Staten blijkt dat deze 'compensating wage differentials' kunnen oplopen tot $25 \%$ (Stern, 1999). De tweede verklaring van de relatieve omvang van crowding-out-effecten houdt verband met de internationale mobiliteit van kenniswerkers. Sectoren waarin Nederlandse kenniswerkers makkelijker te vervangen zijn door buitenlandse kenniswerkers, zullen crowding-outeffecten beter kunnen opvangen dan sectoren waarin die substitutie moeilijker is.

In de volgende twee paragrafen worden de opleidingsachtergronden van kenniswerkers in de verschillende bedrijfssectoren van de Nederlandse economie in beeld gebracht. De inzet van buitenlandse R\&D-werkers wordt besproken in hoofdstuk 5 . In paragraaf 4.6 wordt, aan de hand van het binnenkort te verschijnen ROA-rapport Crowding out in the Dutch labour market for R\&D workers (ROA, 2002), nader ingegaan op de vraag in hoeverre crowding-out-effecten tussen sectoren van de Nederlandse economie daadwerkelijk optreden.

\subsection{Opleidingsachtergronden van onderzoekers naar bedrijfssector}

De meest voor de hand liggende risicofactor met betrekking tot crowding-out is de mogelijke similariteit in opleidingsachtergronden van onderzoekers in verschillende bedrijfssectoren van de Nederlandse economie. Tabel 4.5 toont de belangrijkste (d.w.z. een aandeel van tenminste 10\%) opleidingsachtergronden van onderzoekers per bedrijfssector.

Onderzoekers met een WO wiskunde en natuurwetenschappen opleiding spelen een cruciale rol in R\&D. Ze zijn de belangrijkste uitvoerders van R\&D in de metaalindustrie, de chemische industrie, researchondernemingen en overheidsinstellingen. In de voedings- en genotmiddelenindustrie, verkeer, communicatie en zakelijke dienstverlening en landbouw \& visserij zijn ze de op een na belangrijkste groep. Hun wijdverbreide rol in R\&D-activiteiten maakt ze een belangrijke kandidaat voor crowding-out-mechanismen. 
Tabel 4.5

Belangrijkste opleidingsachtergronden van onderzoekers per bedrijfssector, 1997-2000

\begin{tabular}{|c|c|c|}
\hline Bedrijfssector & Opleidingstype & $\begin{array}{l}\% \text { aandeel in } \\
\text { bedrijfssector }\end{array}$ \\
\hline \multirow[t]{4}{*}{ Metaalindustrie } & WO wiskunde en natuurwetenschappen & 21 \\
\hline & WO werktuigbouwkunde & 16 \\
\hline & WO electrotechniek & 11 \\
\hline & HBO werktuigbouwkunde & 11 \\
\hline \multirow[t]{2}{*}{ Chemische industrie } & WO wiskunde en natuurwetenschappen & 35 \\
\hline & HBO laboratorium & 13 \\
\hline Voedings- en & WO economie & 28 \\
\hline \multirow[t]{3}{*}{ genotmiddelenindustrie } & WO wiskunde en natuurwetenschappen & 16 \\
\hline & WO (technische) bedrijfskunde & 12 \\
\hline & WO werktuigbouwkunde & 10 \\
\hline \multirow{3}{*}{$\begin{array}{l}\text { Verkeer, communicatie en } \\
\text { zakelijke dienstverlening }\end{array}$} & WO bouwkunde & 12 \\
\hline & WO wiskunde en natuurwetenschappen & 11 \\
\hline & WO economie & 11 \\
\hline \multirow[t]{3}{*}{ Landbouw en visserij } & WO landbouw en milieukunde & 53 \\
\hline & WO wiskunde en natuurwetenschappen & 28 \\
\hline & HBO laboratorium & 19 \\
\hline \multirow[t]{3}{*}{ Researchondernemingen } & WO wiskunde en natuurwetenschappen & 42 \\
\hline & WO economie & 33 \\
\hline & WO sociale wetenschappen & 12 \\
\hline \multirow[t]{2}{*}{ Overige industrie } & WO civiele techniek & 11 \\
\hline & WO electrotechniek & 10 \\
\hline Universiteiten* & - & - \\
\hline \multirow[t]{2}{*}{ Overheidsinstellingen } & WO wiskunde en natuurwetenschappen & 30 \\
\hline & WO sociale wetenschappen & 11 \\
\hline $\begin{array}{l}\text { Particuliere non-profit* } \\
\text { organisaties }\end{array}$ & - & - \\
\hline
\end{tabular}

* onvoldoende celvulling.

Bron: CBS/ROA

Werktuigbouwkundigen zijn verantwoordelijk voor een aanzienlijke hoeveelheid R\&D in de metaalindustrie en de voedings- en genotmiddelenindustrie. Electrotechnisch ingenieurs voeren een belangrijk aandeel uit van de R\&D in de metaalindustrie en de overige industrie. Mensen met een $\mathrm{HBO}$ laboratorium achtergrond spelen een grote rol in zowel de chemische industrie en landbouw \& visserij. Economen en (technisch) bedrijfskundigen zijn in grote mate betrokken bij R\&D in de voedings- en genotmiddelenindustrie, vervoer, communicatie en zakelijke dienstverlening en researchondernemingen. Sociale wetenschappers spelen een rol in researchondernemingen en overheidsinstellingen.

Aangezien wiskundigen en natuurwetenschappers zo'n grote rol spelen in R\&D is het van belang een gedetailleerder beeld te krijgen van de verschillende studierichtingen binnen dit opleidingstype. Daarom bekijken we in de volgende paragraaf de KIvl Salarisenquête die een beeld geeft van de afgestudeerden van technische universiteiten. 


\subsection{Studierichtingen van onderzoekers met een TU-opleiding naar bedrijfssector}

In tabel 4.6 worden de belangrijkste (tenminste een aandeel van 10\%) studierichtingen van afgestudeerden van technische universiteiten die werkzaam zijn in R\&D weergegeven naar bedrijfssector. De tabel is gebaseerd op de Salarisenquête 1997 van het Koninklijk Instituut van Ingenieurs (KIvl), waarin verschillende aspecten van de arbeidsvoorwaarden van afgestudeerden aan technische universiteiten in 1997 worden gemeten (Koninklijk Instituut van Ingenieurs, 1998). ${ }^{15}$ Deze enquête werd uitgevoerd door NSS Research and Consultancy BV, waarbij een andere classificatie van bedrijfssectoren is gebruikt dan de SBI van het CBS. Aangezien het niet mogelijk was een exacte match tussen de twee classificaties te krijgen, zijn de resultaten gepresenteerd in de originele classificatie. Merk op dat de tabel geen expliciete informatie bevat over de volgende door het CBS onderscheiden bedrijfssectoren: de voedings- en genot-middelenindustrie, landbouw \& visserij en particuliere non-profit organisaties. Met betrekking tot de opleidingsachtergronden moet vermeld worden dat geen informatie beschikbaar is over landbouwkundig ingenieurs aangezien deze niet worden opgeleid aan technische universiteiten (Delft, Eindhoven, Twente), maar in Wageningen.

De meest voor de hand liggende kandidaten voor crowding-out-mechanismen zijn TU-ingenieurs met een studierichting die een belangrijke rol speelt in de R\&D van verschillende sectoren van de economie. Elektrotechnisch ingenieurs hebben in het bijzonder een wijdverbreide en significante aanwezigheid in R\&D-activiteiten in de Nederlandse economie: ze nemen meer dan een kwart van de R\&D voor hun rekening (d.w.z. voorzover uitgevoerd door TU-ingenieurs) in de elektrotechnische industrie, verkeer, vervoer en telecommunicatie, ingenieursbureaus, softwarebedrijven en andere zakelijke dienstverlening en meer dan een tiende in gas, water \& elektriciteit, overige overheidsdiensten en hoger onderwijs. Technisch natuurkundigen zijn ook alom aanwezig in R\&D: ze zijn verantwoordelijk voor meer dan een tiende van R\&D in de metaalindustrie, elektrotechnische industrie, chemische industrie, verkeer, vervoer en telecommunicatie, bouwnijverheid, overige industrie, gas, water en elektriciteit, overige overheidsdiensten, hoger onderwijs en de sector 'overige' (welke ook de landbouw \& visserij omvat). Werktuigbouwkundig ingenieurs zijn verantwoordelijk voor meer dan $10 \%$ van R\&D in de metaalindustrie, de elektrotechnische industrie, overige industrie, gas, water en elektriciteit, ingenieursbureaus, overige zakelijke dienstverlening en hoger onderwijs. Civiel ingenieurs nemen driekwart van de R\&D bij publieke werken en waterstaat voor hun rekening, een derde in de bouwnijverheid en een vijfde in het hoger onderwijs. Chemisch technologen zijn verantwoordelijk voor $60 \%$ van de R\&D in de chemische

15. Hoewel de KIvl Salarisenquête 2000 meer recente informatie bevat, is het aantal onderscheiden studierichtingen teruggebracht van 14 naar 9. Derhalve worden de gegevens voor 2000 niet gebruikt bij de opleidingsachtergronden in deze paragraaf, maar wel bij de lonen naar sector en functie in paragraaf 4.8 . 
industrie, $40 \%$ in gas, water en elektriciteit en ongeveer $28 \%$ in de overige industrie en de sector 'overige' (incl. landbouw \& visserij).

Tabel 4.6

Belangrijkste studierichtingen van onderzoekers met een TU-opleiding, naar bedrijfssector, 1997

\begin{tabular}{|c|c|c|}
\hline Bedrijfssector & Studierichting & $\begin{array}{l}\% \text { aandeel in } \\
\text { bedrijfssector }\end{array}$ \\
\hline \multirow[t]{3}{*}{ Elektrotechnische industrie } & Elektrotechniek & 62 \\
\hline & Werktuigbouwkunde & 15 \\
\hline & Technische natuurkunde & 14 \\
\hline \multirow{4}{*}{$\begin{array}{l}\text { Metaalindustrie (enge zin), scheeps- en } \\
\text { machinebouw en transportmiddelenindustrie } \\
\text { Chemische industrie }\end{array}$} & Werktuigbouwkunde & 52 \\
\hline & Technische natuurkunde & 14 \\
\hline & Chemische technologie & 60 \\
\hline & Technische natuurkunde & 23 \\
\hline \multirow[t]{3}{*}{ Verkeer, vervoer en communicatie } & Elektrotechniek & 45 \\
\hline & Informatica & 24 \\
\hline & Technische natuurkunde & 23 \\
\hline \multirow{3}{*}{$\begin{array}{l}\text { Ingenieurs-, architecten-, organisatie-, advies- } \\
\text { en octrooibureaus }\end{array}$} & Elektrotechniek & 29 \\
\hline & Werktuigbouwkunde & 22 \\
\hline & Industrieel ontwerpen & 10 \\
\hline \multirow[t]{3}{*}{ Automatisering/Softwarebureaus } & Elektrotechniek & 35 \\
\hline & Informatica & 28 \\
\hline & Technische natuurkunde & 14 \\
\hline \multirow[t]{2}{*}{ Overige dienstverlening - niet-overheid } & Elektrotechniek & 35 \\
\hline & Werktuigbouwkunde & 32 \\
\hline \multirow[t]{4}{*}{ Bouwnijverheid } & Bouwkunde & 40 \\
\hline & Civiele techniek & 35 \\
\hline & Industrieel ontwerpen & 13 \\
\hline & Technische natuurkunde & 12 \\
\hline \multirow[t]{4}{*}{ Gas, water en electriciteit } & Chemische technologie & 40 \\
\hline & Technische natuurkunde & 25 \\
\hline & Elektrotechniek & 18 \\
\hline & Werktuigbouwkunde & 16 \\
\hline \multirow[t]{4}{*}{ Overige industrie } & Chemische technologie & 28 \\
\hline & Werktuigbouwkunde & 24 \\
\hline & Industrieel ontwerpen & 19 \\
\hline & Technische natuurkunde & 15 \\
\hline \multirow[t]{4}{*}{ Hoger onderwijs } & Civiele techniek & 18 \\
\hline & Technische natuurkunde & 18 \\
\hline & Werktuigbouwkunde & 17 \\
\hline & Elektrotechniek & 13 \\
\hline \multirow[t]{2}{*}{ Publieke werken, Waterstaat } & Civiele techniek & 77 \\
\hline & Mijnbouwkunde & 14 \\
\hline \multirow[t]{2}{*}{ Overige dienstverlening - overheid } & Technische natuurkunde & 30 \\
\hline & Elektrotechniek & 16 \\
\hline \multirow[t]{3}{*}{ Overige (incl. landbouw en visserij) } & Technische natuurkunde & 32 \\
\hline & Chemische technologie & 29 \\
\hline & Werktuigbouwkunde & 10 \\
\hline
\end{tabular}

Aandeel heeft alleen betrekking op R\&D uitgevoerd door TU-ingenieurs. Bron: KIvl/ROA

\subsection{Crowding-out-effecten: empirische resultaten}

In het rapport Crowding out in the Dutch labour market for R\&D workers (Marey, 2002) wordt verslag gedaan van de resultaten van een empirisch onderzoek naar 
crowding-out-effecten op de Nederlandse arbeidsmarkt voor kenniswerkers. Voor het onderzoek is een econometrisch model voor crowding-out ontwikkeld, gebaseerd op coïntegratie-analyse van tijdreeksen uit de R\&D-enquête van het CBS. Hierbij wordt onderscheid gemaakt tussen korte-termijn-elasticiteiten en lange-termijn-elasticiteiten zodat de dynamiek op de arbeidsmarkt voor kenniswerkers beter in beeld gebracht wordt. In het model komen mogelijke effecten van R\&D-activiteiten in de publieke sfeer op het bedrijfsleven tot uiting in de crowding-out-effecten van overheidsinstellingen en universiteiten op verschillende sectoren van het bedrijfsleven. De overige crowding-out-effecten geven de gevolgen weer van private R\&D-activiteiten op andere sectoren van het bedrijfsleven en de publieke sector. Hierbij wordt geen onderscheid gemaakt tussen publieke en private financiering van R\&D-uitgaven in het bedrijfsleven. Deze crowding-out-effecten kunnen dus zowel veroorzaakt worden door R\&D-uitgaven die uit eigen middelen of op de kapitaalmarkt gefinancierd zijn als door R\&D-uitgaven die uit publieke middelen komen.

Tabel 4.7

Crowding-out-effecten op de Nederlandse arbeidsmarkt voor kenniswerkers, 1973-1993

\begin{tabular}{ll} 
Sector & Crowding out door: \\
\hline \multirow{2}{*}{ Metaalindustrie } & Chemische industrie \\
& Universiteiten \\
Chemische industrie & Overheidsinstellingen \\
& Metaalindustrie \\
& Landbouw en visserij \\
Voedings- en genotmiddelenindustrie & Universiteiten \\
& Overheidsinstellingen \\
& Metaalindustrie \\
Vervoer, communicatie en zakelijke & Chemische industrie \\
dienstverlening & Universiteiten \\
& Overheidsinstellingen \\
& Metaalindustrie \\
Landbouw en visserij & Chemische industrie \\
Researchondernemingen & Universiteiten \\
Overige industrie & Overheidsinstellingen \\
Universiteiten & - \\
Overheidsinstellingen & Particuliere non-profit organisaties \\
Particuliere non-profit organisaties & - \\
& - \\
& -
\end{tabular}

Bron: Marey (2002)

De schattingsresultaten (samengevat in tabel 4.7) tonen aan dat de metaalindustrie, de chemische industrie, de voedings- en genotmiddelenindustrie en de sector vervoer, communicatie en zakelijke dienstverlening last hebben van crowding-out door overheidsinstellingen en universiteiten. Andersom heeft de publieke sector geen last van crowding-out, noch vanuit het bedrijfsleven, noch binnen de publieke sector zelf, tussen overheidsinstellingen en universiteiten. Hiervoor zijn twee verklaringen. De eerste houdt verband met het meer dan gemiddelde percentage buitenlandse kenniswerkers in de publieke sector (zie tabel 5.1): blijkbaar worden personeelstekorten aangevuld via de internationale arbeidsmarkt voor kenniswerkers. De 
tweede verklaring is de voorkeur voor fundamenteel onderzoek van een groot aantal onderzoekers (zie tabel 4.10). Het gevolg is dat het stimuleren van private R\&D geen crowding-out-effecten lijkt te hebben op de publieke R\&D. In dit opzicht hoeft er dus geen trade-off gemaakt te worden door de overheid. Hierbij moet worden opgemerkt dat door de herdefiniëring van universitaire R\&D de econometrische analyse beperkt is tot de periode 1973-1993.

Crowding out binnen het bedrijfsleven vindt plaats in een aantal bedrijfstakken. De metaalindustrie en de chemische industrie hebben crowding-out-effecten op elkaar, maar ook op de voedings- en genotmiddelenindustrie en de sector vervoer, communicatie en zakelijke dienstverlening. Een belang-rijke rol in deze processen spelen natuurkundigen, chemici, elektrotechnisch ingenieurs en werktuigbouwkundig ingenieurs. De landbouw en visserij hebben crowding-out-effecten op de chemische industrie, hierbij gaat het met name om WO-ers natuurwetenschappen en HBO-ers laboratorium. Tenslotte hebben researchondernemingen last van crowding-outeffecten van particuliere non-profit organisaties. Hierbij spelen zowel natuurwetenschappers als economen en sociologen een rol.

Deze empirische resultaten benadrukken de betekenis die internationale arbeidsmobiliteit van R\&D-werkers kan spelen in het opvangen van crowding-out-effecten tussen sectoren van de Nederlandse economie. Een aantrekkelijk onderzoeksklimaat stimuleert niet alleen de instroom van buitenlandse onderzoekers, maar heeft ook een remmende werking op de uitstroom van Nederlandse R\&D-werkers. Momenteel spelen buitenlandse onderzoekers vooral een rol in de publieke sector. Samen met de onderzoeksvoorkeuren van Nederlandse onderzoekers verklaart dit het ontbreken van crowding-out-effecten in de publieke sector. Het stimuleren van private R\&D lijkt derhalve geen negatieve gevolgen te hebben voor publieke R\&D, zolang overheidsinstellingen en universiteiten voldoende buitenlandse onderzoekers weten aan te trekken. Beleidsmaatregelen die erop gericht zijn de instroom van buitenlandse kenniswerkers in het bedrijfsleven te stimuleren zouden een belangrijke bijdrage kunnen leveren in het opvangen van de crowding-out-effecten die nu in bepaalde sectoren optreden.

\subsection{Knelpunten in de personeelsvoorziening van universiteiten tot 2008}

Universiteiten spelen een cruciale rol in de kenniseconomie. In de eerste plaats worden hier kenniswerkers opgeleid en in de tweede plaats wordt hier fundamenteel onderzoek verricht. Van Dijk \& Webbink (2000) geven prognoses voor de arbeidsmarkt voor wetenschappelijk personeel op universiteiten tot 2008. Hierbij veronderstellen zij dat de werkgelegenheid voor wetenschappelijk personeel in 2008 gelijk is aan 1998, m.a.w. de uitbreidingsvraag is nul. Deze veronderstelling is mede gebaseerd op prognoses van het Ministerie van OcenW die aangeven dat de studentenaantallen naar verwachting stabiel blijven in deze periode. Met betrekking tot het aanbod van wetenschappelijk personeel wordt aangenomen dat dit grotendeels afhangt van de leeftijdsopbouw van het huidige personeelsbestand en historische netto instroomcoëfficiënten. De prognoses zijn weergegeven in tabel 4.8. 
Tabel 4.8

Verwachte tekorten en overschotten wetenschappelijk personeel universiteiten 1998-2008

$$
\begin{array}{lllllr}
\text { AIO Postdoc UD UHD Prof Tekort } & \begin{array}{l}
\text { Over- } \\
\text { schot }
\end{array} & \begin{array}{r}
\text { Tekort* } \\
(\%)
\end{array}
\end{array}
$$

\begin{tabular}{lrrrrrrrr}
\hline Landbouw & -8 & -29 & -113 & -35 & -23 & -208 & 0 & $-17,0 \%$ \\
Natuur & -41 & 141 & -102 & -135 & -77 & -355 & 141 & $-9,1 \%$ \\
Techniek & 262 & 403 & -290 & -92 & -54 & -436 & 665 & $-10,8 \%$ \\
Gezondheid & -66 & 101 & -335 & -154 & -42 & -597 & 101 & $-11,2 \%$ \\
Economie & 12 & 127 & -160 & -55 & 39 & -215 & 178 & $-14,6 \%$ \\
$\begin{array}{l}\text { Recht } \\
\text { Gedrags- en }\end{array}$ & 12 & 32 & -151 & -41 & 46 & -192 & 90 & $-12,9 \%$ \\
maatschapij & & & & & & & & \\
wetenschappen & 4 & -196 & -172 & -115 & 1 & -483 & 5 & $-17,2 \%$ \\
Taal \& Cultuur & 18 & -42 & -204 & -91 & 34 & -337 & 52 & $-14,0 \%$ \\
& & & & & & & & \\
Totaal tekort & $-2,0 \%$ & $-5,0 \%$ & $-25,8 \%$ & $-27,4 \%$ & $-7,9 \%$ & -2886 & 1315 & $-12,1 \%$ \\
& & & & & & & &
\end{tabular}

* Tekorten als percentage van de werkgelegenheid in 1998.

Bron: van Dijk \& Webbink (2000)

Tekorten worden verwacht voor wetenschappelijk personeel in alle vakgebieden, in het bijzonder voor UD's en UHD's. Op het niveau van hoogleraren is er een duidelijk verschil tussen de beta-wetenschappen en andere vakgebieden. Tekorten worden verwacht voor landbouw, techniek, natuur en gezondheid, terwijl er overschotten worden voorzien voor economie, recht, taal \& cultuur. Voor hoogleraren gedrags- en maatschappijwetenschappen lijkt de arbeidsmarkt ongeveer in evenwicht tot 2008. Voor postdoc's en AIO's zien we een gemengd beeld. Bij techniek, economie en recht is er naar verwachting sprake van overschotten op beide niveau's, voor landbouw daarentegen tekorten. Voor natuur en gezondheid wordt een overschot aan postdoc's en een tekort aan AIO's verwacht; voor gedrags- en maatschappijwetenschappen en taal \& cultuur het tegenovergestelde.

Uiteraard berust de door van Dijk \& Webbink (2000) gehanteerde prognosemethode op een partiële analyse van de arbeidsmarkt: de arbeidsmarkt voor wetenschappelijk personeel wordt namelijk beïnvloed door ontwikkelingen op de arbeidsmarkt voor kenniswerkers in zijn geheel. In hoofdstuk 3 zagen we dat er op basis van de ROAanalyse van de arbeidsmarkt als geheel grote tot zeer grote knelpunten worden verwacht tot 2006 voor alle onderzoeksberoepsgroepen, met uitzondering van landbouwkundigen (tabel 3.11). Dit betekent dat er vanuit het bedrijfsleven en de overheid een aanzuigende werking zal blijven optreden, met name voor (potentiële) postdoc's en AIO's. Daarentegen kan de op gang gekomen instroom van buitenlandse onderzoekers enige verlichting van de knelpunten blijven bieden. Tegelijkertijd oefent het buitenland ook aantrekkingskracht uit op in Nederland werkzame - Nederlandse en buitenlandse - onderzoekers. De Enquête Buitenlandervaring van Research voor Beleid (Bos \& Keizer, 2001) biedt informatie over de arbeidsmarktverwachtingen en -plannen in 2001 van wetenschappelijk universitair personeel voor 2006 (tabel 4.9). 
Tabel 4.9

Toekomstverwachtingen wetenschappelijk personeel universiteiten voor 2006, percentages

$\begin{array}{lrrr}\text { Verwachte werkkring in 2006 } & \text { AIO } & \text { UD/UHD } & \text { Prof } \\ & & 55 & 65 \\ \text { Nederlandse universiteit } & 32 & & -(-) \\ \text { ('zeker of waarschijnlijk nog aan Nederlandse universiteit') } & & -(-) & -(-) \\ \text { Academisch ziekenhuis (in de wetenschap) } & 5 & -(-) & 65 \\ \text { Nederlands publiek onderzoeksinstituut } & 6 & 55 & 1(5) \\ \text { Totaal wetenschap publieke sector Nederland } & 43 & 3(15) & -(-) \\ \text { Buitenlandse universiteit } & 17 & 0(2) & -(-) \\ \text { Onderwijs (niet-universitair) } & 2 & 0(1) & -(-) \\ \text { Zorg } & 7 & 0(2) & -(-) \\ \text { Andere (semi)overheidssector dan onderwijs of zorg } & 7 & 2(13) & 13(76) \\ \text { Bedrijfsleven } & 19 & -11(56) & 3(19) \\ \text { Gestopt met werken } & - & 2(11) & 18 \\ \text { Anders } & 6 & 26 & \end{array}$

Tussen haakjes percentages van respondenten die 'zeker of waarschijnlijk niet meer aan Nederlandse universiteit' invulden.

Bron: Enquête Buitenlandervaring 2001, Research voor Beleid; Figuur 6.1 en Tabel 6.1 van Bos \& Keizer (2001)

Naarmate de wetenschappelijke rang (en leeftijd) toeneemt bestaat er een sterkere verwachting dat men in 2006 werkzaam zal zijn op een Nederlandse universiteit en neigt men minder naar een baan aan een buitenlandse universiteit. Het bedrijfsleven oefent een ongeveer even grote aantrekkingskracht uit op AIO's en UD/UHD's als buitenlandse universiteiten. Helaas bevat de Enquête Buitenlandervaring geen informatie over het soort werk dat men verwacht te gaan doen in het bedrijfsleven, in het bijzonder of men zich met (private) R\&D gaat bezighouden. Opvallend is het grote percentage twijfelaars bij UD/UHD's en hoogleraren.

Tabel 4.10

Voorkeuren AIO's en postdoc's

\begin{tabular}{lcll} 
Meest van invloed & \multicolumn{2}{l}{ Minst van invloed } \\
\hline $\begin{array}{l}\text { Benutten van eigen } \\
\text { vaardigheden }\end{array}$ & 5.92 & Salariëring & 3.08 \\
$\begin{array}{l}\text { Intellectuele uitdaging } \\
\text { Zelfstandigheid }\end{array}$ & 5.90 & $\begin{array}{l}\text { Maatschappelijke status } \\
\text { Invloed op beleid en organisatie }\end{array}$ & 3.22 \\
& 5.54 & 3.40
\end{tabular}

Bron: Arbeidsmarktenquête Jonge Wetenschappers, Ondernemingsraad Projectmedewerkers NWO en LIAOO, 2000; Tabel 4.3 van Bos \& Keizer (2001)

De afwezigheid van crowding-out van universiteiten door R\&D in het bedrijfsleven of (semi-)overheidsinstellingen voor de periode 1973-1993 (zie paragraaf 4.6), suggereert dat stijgende lonen buiten de universiteiten niet noodzakelijk tot problemen in de personeelsvoorziening van universiteiten hoeven te leiden. De universiteit kan een aantrekkelijke werkgever zijn op basis van secundaire arbeidsvoorwaarden die goed aansluiten bij de persoonlijke voorkeuren van onderzoekers. Uit tabel 4.10 blijkt 
namelijk dat aan salariëring weinig gewicht wordt toegekend door jonge onderzoekers.

\subsection{Lonen van TU-ingenieurs in de publieke en private sector}

De financiële prikkels in de loopbaankeuze van TU-ingenieurs worden weergegeven in tabel 4.11, welke is gebaseerd op de KIvl Salarisenquête over 2000 (KIvl, 2001), uitgevoerd door Survey Marktonderzoek BV. Hierbij maken we onderscheid tussen vier soorten banen: een R\&D-functie in het bedrijfsleven, een andere functie in het bedrijfsleven, een R\&D-functie in de publieke sector of een andere functie in de publieke sector. Het bruto mediaaninkomen is voor elk van de vier soorten banen weergegeven per leeftijdscohort. Hiermee wordt in de eerste plaats het effect van de leeftijdsstructuur op het loon beperkt en in de tweede plaats schetsen we zo een beeld van de financiële prikkels die TU-ingenieurs in de loop van hun carrière krijgen bij de keuze tussen werken in het bedrijfsleven of de publieke sector en de keuze tussen een baan waar de nadruk op R\&D ligt of andere banen. ${ }^{16}$

Tabel 4.11

Lonen van TU-ingenieurs naar sector en functie, 2000

\begin{tabular}{|c|c|c|c|}
\hline Leeftijdscohort & $\begin{array}{l}\text { Bedrijfsleven, } \\
\text { R\&D-functie }\end{array}$ & $\begin{array}{l}\text { Bedrijfsleven, } \\
\text { niet-R\&D-functie }\end{array}$ & $\begin{array}{r}\text { Overheid \& } \\
\text { onderwijs, } \\
\text { R\&D-functie }\end{array}$ \\
\hline
\end{tabular}

\begin{tabular}{lrrrr}
\hline & & & & 60.500 \\
t/m 29 jaar & 68.500 & 67.500 & 77.000 & 62.000 \\
$30-34$ jaar & 91.000 & 89.000 & 99.000 & 108.000 \\
$35-39$ jaar & 97.500 & 120.000 & 105.500 & 105.000 \\
$40-44$ jaar & 119.000 & 134.000 & 110.000 & 118.500 \\
$45-49$ jaar & 163.500 & 153.000 & 152.000 & 140.500 \\
$50-54$ jaar & 153.500 & 171.000 & 144.000 & 134.000 \\
$55-59$ jaar & 153.000 & 193.000 & 137.000 & 153.500 \\
$60-64$ jaar & 125.000 & 179.000 & & \\
\hline
\end{tabular}

Mediaan bruto jaarinkomen over 2000 in guldens, afgerond op vijfhonderdtallen.

Bron: KIvl/ROA

De salarissen voor TU-ingenieurs werkzaam in niet-R\&D-functies liggen in het bedrijfsleven hoger dan in de publieke sector, dit geldt voor alle leeftijdscohorten. Bovendien is het inkomensverschil voor veertigplussers groter dan voor twintigers en dertigers. Dit betekent dat er voor elk leeftijdscohort van TU-ingenieurs werkzaam in een niet-R\&D-functie in de publieke sector een financiële prikkel bestaat om over te stappen naar het bedrijfsleven, die ook nog eens toeneemt met de leeftijd.

Voor R\&D-functies lijkt ${ }^{17}$ deze financiële prikkel ook aanwezig in de meeste leeftijdscohorten. Uit tabel 4.10 bleek echter dat met name voor jonge onderzoekers financiële prikkels een bescheiden rol spelen in de baankeuze. De concurrentie-

16. Uiteraard wordt het beeld enigszins vertekend door cohort-effecten: ingenieurs die afstudeerden in een krappe arbeidsmarkt zullen hogere aanvangssalarissen hebben ontvangen, die doorwerken op het salaris op latere leeftijd.

17. De celvulling voor R\&D-functies is ongeveer een zesde van die voor niet-R\&D-functies, dus de gegevens zijn iets minder betrouwbaar. 
positie van de publieke sector ten opzichte van het bedrijfsleven op de arbeidsmarkt voor onderzoekers is dus niet zo zwak als op basis van salarisverschillen geconcludeerd zou kunnen worden. De afwezigheid van crowding-out-effecten van R\&D-uitgaven in het bedrijfsleven op de omvang van het R\&D-personeel in de publieke sector in tabel 4.7 bevestigt dit beeld.

Voor TU-ingenieurs werkzaam in de publieke sector lijken niet-R\&D-functies financieel meer op te leveren dan R\&D-functies. Zodra TU-ingenieurs eenmaal in het bedrijfsleven werken lijkt een R\&D-functie financieel even aantrekkelijk te zijn als een niet-R\&D-functie totdat men een jaar of vijfendertig is. Tussen de 35 en 45 betalen niet-R\&D-functies beter. Een carrière als onderzoeker is in financieel opzicht dus weinig interessant, tenzij men zich beperkt tot het begin van de loopbaan in het bedrijfsleven. 


\section{Buitenlandse kenniswerkers in Nederland}

Een belangrijk mechanisme om crowding-out-effecten op te vangen is internationale arbeidsmobiliteit. Bedrijfssectoren die makkelijker Nederlandse onderzoekers kunnen vervangen door buitenlandse onderzoekers zijn beter in staat de gevolgen van crowding-out te absorberen dan sectoren waarin die substitutie minder vlot verloopt. Aan de andere kant kan eenzelfde substitutieproces ook in het buitenland plaatsvinden, waardoor 'brain-drain'-effecten kunnen optreden in de andere richting. In dit geval is er sprake van een geïntegreerde internationale arbeidsmarkt voor onderzoekers. Welk effect domineert (inwaarts of uitwaarts) vergt een aparte studie, maar we kunnen wel een idee krijgen van de mate waarin de verschillende sectoren van de Nederlandse economie gebruik maken van buitenlandse kenniswerkers aan de hand van tabel 5.1. Wat 'brain-drain-effecten' betreft biedt de R\&D-enquête geen informatie. De Enquête Beroepsbevolking (EBB) daarentegen bevat informatie over etniciteit, hoewel een exacte identificatie van brain-drain-werkers niet mogelijk is. Daarom worden in tabel 5.1 alle niet-Nederlanders en allochtone Nederlanders als buitenlandse werknemers gerekend. Dit impliceert een overschatting van de daadwerkelijke aanwezigheid van buitenlandse kenniswerkers, maar als de opwaartse vertekening van even grote omvang is over alle sectoren, is het relatieve brain-drain patroon toch informatief. We zijn tenslotte geïnteresseerd in het relatieve vermogen van verschillende sectoren van de economie om crowding-out-effecten op te vangen door middel van internationale arbeidsmobiliteit. Voor onderzoekers is het plausibel te veronderstellen dat de opwaartse vertekening vergelijkbaar is tussen de verschillende sectoren. In het algemeen hebben allochtone Nederlanders een grotere aanwezigheid in niet-HRST-beroepen dan in HRST-beroepen. Positieve discriminatie regelgeving voor HRST-beroepen is relatief nieuw en heeft waarschijnlijk een kleiner effect op onderzoeksbanen dan op andere HRST-banen, dus de opwaartse vertekening is waarschijnlijk niet groter in de publieke sector dan in het bedrijfsleven.

Tabel 5.1 geeft het percentage buitenlandse kenniswerkers naar bedrijfssector. Universiteiten en overheidsinstellingen hebben een relatief hoog percentage buitenlandse onderzoekers, hetgeen aangeeft dat in de publieke R\&D-sector crowding-out-effecten worden geabsorbeerd door het aantrekken van buitenlandse kenniswerkers. Daarentegen zijn in het bedrijfsleven relatief weinig buitenlandse onderzoekers werkzaam in landbouw \& visserij en particuliere non-profit organisaties. In de EBB werden er zelfs geen buitenlandse onderzoekers gevonden tussen 1997 en 2000. Dit betekent dat deze sectoren nog geen tekorten aan onderzoekers hebben ondervonden of dat substitutie-mogelijk-heden beperkt zijn. In het laatste geval kunnen deze sectoren de inter-nationale mobiliteit van kenniswerkers niet gebruiken om crowding-out-effecten op te vangen. Merk op dat het percentage buitenlandse onderzoekers hoger is dan het percentage buitenlandse werknemers met een HBO-WO opleiding. Dit betekent dat buitenlandse kenniswerkers vaker aangetrokken worden voor een baan als onderzoeker dan voor andere banen. 
Tabel 5.1

Buitenlandse kenniswerkers in Nederland, naar bedrijfssector, 1997-2000

\begin{tabular}{|c|c|c|c|}
\hline Sector & $\begin{array}{c}\begin{array}{c}\text { Werknemers } \\
\text { totaal }\end{array} \\
\% \text { buitenlanders }\end{array}$ & $\begin{array}{c}\text { Werknemers met een } \\
\text { HBO-WO opleiding } \\
\text { \% buitenlanders }\end{array}$ & $\begin{array}{l}\text { Onderzoekers } \\
\text { \% buitenlanders }\end{array}$ \\
\hline Metaalindustrie & 12.4 & 7.8 & 11.1 \\
\hline $\begin{array}{l}\text { Chemische industrie } \\
\text { Voedings- en }\end{array}$ & 11.1 & 9.1 & 10.2 \\
\hline $\begin{array}{l}\text { genotmiddelen industrie } \\
\text { Vervoer, communicatie en }\end{array}$ & 13.0 & 10.6 & 9.9 \\
\hline zakelijke dienstverlening & 9.6 & 9.7 & 9.7 \\
\hline Landbouw en visserij & 5.0 & 1.5 & $1.5^{*}$ \\
\hline Researchondernemingen & 6.9 & 7.0 & 11.2 \\
\hline Overig bedrijfsleven & 7.1 & 6.8 & 10.3 \\
\hline Universiteiten & 15.6 & 17.1 & $17.1^{*}$ \\
\hline Overheidsinstellingen & 7.9 & 7.5 & 13.8 \\
\hline $\begin{array}{l}\text { Particuliere non-profit } \\
\text { organisaties } \\
\text { Alle sectoren }\end{array}$ & $\begin{array}{l}5.0 \\
9.2\end{array}$ & $\begin{array}{l}1.8 \\
8.7\end{array}$ & $\begin{array}{c}1.8^{*} \\
10.1\end{array}$ \\
\hline
\end{tabular}




\section{Kenniswerkers in het buitenland}

\subsection{De Nederlandse arbeidsmarkt voor kenniswerkers in internationaal perspectief}

De HRST-groep in Nederland bestond in 2000 uit 3.747 .000 personen, bijna $30 \%$ van de bevolking ouder dan 15 jaar. Vergeleken met andere lidstaten van de Europese Unie (tabel 6.1) steekt Nederland hiermee gunstig af, alleen in Finland en Zweden maakt de HRST-groep een groter deel uit van de bevolking. Ruim $86 \%$ van de HRST-groep in Nederland is werkzaam, in dit opzicht neemt Nederland binnen de EU de vijfde positie in na Portugal, het Verenigd Koninkrijk, Italië en Denemarken. De HRST-groep in Nederland kent de laagste werkloosheid van de EU met slechts $0,9 \%$. Wat het percentage inactieve leden van de HRST-groep betreft neemt Nederland de vierde positie van onderen in met $12,9 \%$ nog boven het Verenigd Koninkrijk, Italië en Denemarken.

Tabel 6.1

De HRST-groep in de EU, 2000

\begin{tabular}{|c|c|c|c|c|c|}
\hline Lidstaat & $\begin{array}{l}\text { HRST-groep } \\
\text { als percentage } \\
\text { van bevolking } \\
\text { ouder dan } 15 \\
\text { jaar }\end{array}$ & HRST-groep & $\begin{array}{l}\text { Waarvan: } \\
\text { werkzaam } \\
(\%)\end{array}$ & $\begin{array}{c}\text { werkloos } \\
(\%)\end{array}$ & $\begin{array}{c}\text { niet-actief } \\
(\%)\end{array}$ \\
\hline België & 24,8 & 2.088 .000 & 82,8 & 1,8 & 15,4 \\
\hline Denemarken & 27,6 & 1.199 .000 & 87,7 & 1,5 & 10,8 \\
\hline Duitsland & 26,7 & 18.325 .000 & 82,1 & 2,2 & 15,7 \\
\hline Griekenland & 14,1 & 1.250 .000 & 78,1 & 5,3 & 16,6 \\
\hline Spanje & 19,1 & 6.341 .000 & 74,4 & 7,8 & 17,9 \\
\hline Frankrijk & 22,6 & 10.577 .000 & 79,6 & 3,3 & 17,1 \\
\hline lerland & $20,7^{*}$ & $571.000^{*}$ & - & - & - \\
\hline Italië & 14,3 & 6.987 .000 & 87,8 & 2,3 & 9,9 \\
\hline Luxemburg & 22,7 & 79.000 & 84,6 & - & - \\
\hline Nederland & 29,5 & 3.747 .000 & 86,2 & 0,9 & 12,9 \\
\hline Oostenrijk & 19,6 & 1.290 .000 & 85,9 & 1,0 & 13,1 \\
\hline Portugal & 10,2 & 846.000 & 90,8 & - & - \\
\hline Finland & 31,6 & 1.334 .000 & 82,9 & 3,2 & 13,9 \\
\hline Zweden & 29,8 & 2.154 .000 & 84,0 & 1,8 & 14,3 \\
\hline $\begin{array}{l}\text { Verenigd } \\
\text { Koninkrijk }\end{array}$ & 23,2 & 10.936 .000 & 90,5 & 1,7 & 7,9 \\
\hline EU & $22,0^{*}$ & $67.724 .000^{*}$ & - & - & - \\
\hline
\end{tabular}

*) Gegevens voor lerland hebben betrekking op 1997.

Bron: CBS, Tabel 2.4.2, 2.4.3 van Kennis en economie 2001

Wanneer we naar de hoger opgeleiden (HBO en WO) en onderzoekers binnen de HRST-groep kijken (tabel 6.2) ontstaat een genuanceerder beeld van de Nederlandse kenniseconomie. Met het aandeel van de hoger opgeleiden binnen de werkzame beroepsbevolking scoort Nederland met $21,4 \%$ boven het gemiddelde voor de Europese Unie van 19,3\%, maar bevindt zich in de middenmoot met een zevende positie. Het buurland België scoort met $28,6 \%$ het beste in de EU, terwijl 
Duitsland met 22,1\% net boven het Nederlandse aandeel zit. Verder scoren Zweden, Denemarken, lerland en Finland beter dan Nederland. Het Verenigd Koninkrijk heeft met $21,0 \%$ net iets minder hoogopgeleiden in de werkzame beroepsbevolking dan Nederland. Vergelijking van tabel 6.2 met tabel 6.1 duidt erop dat in Nederland relatief veel mensen met een MBO-opleiding werkzaam zijn in HRST-beroepen.

In hoofdstuk 3 bleek al dat een confrontatie tussen de verwachte ontwikkelingen in vraag en aanbod op de Nederlandse arbeidsmarkt voor kenniswerkers op ernstige tekorten wijst voor de periode tot 2006. Dit betekent dat Nederland de komende jaren een kwetsbare positie inneemt als vestigingsplaats voor kennisintensieve bedrijven en organisaties in Noordwest-Europa wanneer we alleen naar knelpunten op de arbeidsmarkt voor kenniswerkers kijken. Uiteraard spelen ook andere factoren zoals geografische ligging, infrastructuur, ruimte en ondernemersklimaat een rol bij de locatie van innovatieve activiteiten. Met name buurland België is gezien het grote aantal hoogopgeleiden en de geografische ligging een belangrijke concurrent voor Nederland.

Tabel 6.2

Hoger opgeleiden en onderzoekers in de EU, 1997

\begin{tabular}{lrrrr}
\hline Lidstaat & $\begin{array}{c}\text { Werkzame } \\
\text { Hoger } \\
\text { opgeleiden }\end{array}$ & $\begin{array}{c}\text { Hoger opgeleiden } \\
\text { als percentage van } \\
\text { werkzame beroeps- } \\
\text { bevolking }\end{array}$ & $\begin{array}{c}\text { Werkzame } \\
\text { onderzoekers }\end{array}$ & $\begin{array}{c}\text { Onderzoekers } \\
\text { als percentage van } \\
\text { werkzame beroeps- } \\
\text { bevolking }\end{array}$ \\
\hline België & 1.091 .000 & 28,6 & 23.000 & 0,60 \\
Denemarken & 670.000 & 25,3 & 18.000 & 0,68 \\
Duitsland & 7.723 .000 & 22,1 & 0,68 \\
Griekenland & 643.000 & 17,3 & 236.000 & 0,30 \\
Spanje & 2.535 .000 & 20,1 & 11.000 & 0,43 \\
Frankrijk & 4.248 .000 & 19,3 & 54.000 & 0,70 \\
lerland & 306.000 & 22,8 & 155.000 & 0,60 \\
Italië & 2.013 .000 & 10,2 & 8.000 & 0,39 \\
Nederland & $\mathbf{1 . 5 2 6 . 0 0 0}$ & $\mathbf{2 1 , 4}$ & 76.000 & $\mathbf{0 , 5 3}$ \\
Oostenrijk & 302.000 & 8,4 & 38.000 & 0,36 \\
Portugal & 487.000 & 11,4 & 13.000 & 0,33 \\
Finland & 464.000 & 22,1 & 14.000 & 0,81 \\
Zweden & 1.002 .000 & 26,0 & 17.000 & 0,96 \\
Verenigd & 5.506 .000 & 21,0 & 37.000 & 0,56 \\
Koninkrijk & & & 147.000 & $\mathbf{0 , 5 7}$ \\
EU & $\mathbf{2 8 . 5 1 6 . 0 0 0}$ & $\mathbf{1 9 , 3}$ & $\mathbf{8 4 7 . 0 0 0}$ & \\
& & & & \\
\hline
\end{tabular}

Bron: Eurostat/OECD; Table 2.1 van Assessing the Supply and Demand for Scientists and Technologists in Europe, Pearson et al. (2001), aangevuld met de OECD Basic Science and Technology Indicators 2000

Wanneer we inzoomen op de harde kern van de hoger opgeleiden, de onderzoekers, lijkt het beeld voor Nederland zorgwekkend. Het percentage onderzoekers in de werkzame beroepsbevolking ligt met $0,53 \%$ beneden het gemiddelde van de EU $(0,57 \%)$ : alleen Oostenrijk en Zuid-Europa scoren slechter. De landen van Noordwest-Europa hebben aanmerkelijk meer onderzoekers in de werkzame beroepsbevolking, variërend van het Verenigd Koninkrijk $(0,56 \%)$ tot Zweden $(0,96 \%)$. Het lage percentage onderzoekers betekent dat relatief weinig mensen zich 
bezig houden met het scheppen van nieuwe kennis. Daartegenover staat wel dat de productiviteit van Nederlandse onderzoekers bijzonder hoog is (Minne, 1995). ${ }^{18}$ Echter de in hoofdstuk 3 voorspelde tekorten voor onderzoeksberoepen suggereren dat eventuele uitbreidingen van R\&D-activiteiten in de komende jaren, door Nederlandse of buitenlandse bedrijven en instellingen, mogelijk afgeremd zullen worden door knelpunten op de arbeidsmarkt. Dit betekent ook dat een deel van eventuele extra R\&D-uitgaven waarschijnlijk zullen neerslaan als hogere lonen voor R\&D-personeel in plaats van extra R\&D-werkers (zie bijvoorbeeld Marey \& Borghans, 2000).

In deze paragraaf blijkt dat de HRST-groep waarschijnlijk een te rooskleurig beeld geeft van de (mens)kracht van de Nederlandse kenniseconomie. Wanneer we kijken naar hoger opgeleiden en onderzoekers ontstaat namelijk een genuanceerder beeld. De in Europees perspectief grote HRST-groep bestaat voor een belangrijk deel uit MBO-ers die werkzaam zijn in een HRST-beroep, bovendien heeft Nederland een relatief kleine groep onderzoekers. De in hoofdstuk 3 voorspelde tekorten voor HRST-beroepen en in het bijzonder onderzoeksberoepen suggereren bovendien dat Nederland een kwetsbare positie heeft als vestigingsplaats voor nieuwe kennisintensieve activiteiten, in het bijzonder R\&D.

Tabel 6.3

Onderzoekers (arbeidsjaren) in lidstaten van de EU naar sector (percentages), 1997

\begin{tabular}{lccccr} 
& $\begin{array}{c}\text { Bedrijfsleven } \\
(\%)\end{array}$ & $\begin{array}{c}\text { Overheid } \\
(\%)\end{array}$ & $\begin{array}{c}\text { Universiteiten } \\
(\%)\end{array}$ & $\begin{array}{c}\text { Particuliere } \\
\text { non-profit- } \\
\text { organisaties } \\
(\%)\end{array}$ & $\begin{array}{r}\text { Totaal aantal } \\
\text { (arbeidsjaren) }\end{array}$ \\
Lidstaat & & & & & \\
\hline België & 50,3 & 4,5 & 44,0 & 1,3 & 23.486 \\
Denemarken & 43,0 & 21,0 & 35,1 & 1,0 & 17.511 \\
Duitsland & 56,3 & 15,9 & 27,9 & - & 235.793 \\
Griekenland & 16,5 & 18,1 & 65,0 & 0,4 & 10.972 \\
Spanje & 22,3 & 19,5 & 56,9 & 1,4 & 53.883 \\
Frankrijk & 46,5 & 15,7 & 35,5 & 2,3 & 154.742 \\
lerland & 65,2 & 3,9 & 28,7 & 2,3 & 7.825 \\
Italië & 36,3 & 18,0 & 45,7 & - & 76.056 \\
Nederland & $\mathbf{4 5 , 5}$ & $\mathbf{2 0 , 5}$ & $\mathbf{3 2 , 7}$ & $\mathbf{1 , 3}$ & $\mathbf{3 8 . 0 5 5}$ \\
Oostenrijk & - & - & - & - & 13.607 \\
Portugal & 8,8 & 21,5 & 55,0 & 14,7 & - \\
Finland & - & - & - & - & 36.878 \\
Zweden & 56,7 & 6,6 & 36,6 & - & 146.546 \\
Verenigd & 57,0 & 8,5 & 32,5 & 1,9 & $\mathbf{8 1 5 . 3 5 4}$ \\
Koninkrijk & & & & & \\
EU* & $\mathbf{4 8 , 3}$ & $\mathbf{1 4 , 5}$ & $\mathbf{3 5 , 9}$ & $\mathbf{1 , 3}$ & \\
\hline
\end{tabular}

${ }^{*}$ excl. Oostenrijk, Finland en Luxemburg.

Bron: OECD, Basic Science and Technology Indicators, 2000

18. Daarnaast heeft Nederland ook relatief weinig high-tech-bedrijven. Voor een discussie van de voor- en nadelen van deze sectorstructuur voor de Nederlandse kenniseconomie, zie hoofdstuk 12 van Jacobs (1999). 
We besluiten deze paragraaf met de spreiding van onderzoekers over bedrijfsleven, overheid, universiteiten en particuliere non-profit-instellingen (tabel 6.3). In Nederland werken relatief veel onderzoekers bij overheidsinstellingen $(20,5 \%)$, alleen in Denemarken en Portugal ligt dit percentage hoger. Daarentegen werken er relatief weinig onderzoekers bij universiteiten $(32,7 \%)$, alleen in Duitsland, lerland en het Verenigd Koninkrijk is dit percentage lager. Particuliere non-profit-organisaties spelen een kleine rol wat betreft het zelf uitvoeren van R\&D met eigen onderzoekers in alle lidstaten van de Europese Unie, met uitzondering van Portugal. Het percentage onderzoekers in het bedrijfsleven ligt in Nederland $(45,5 \%)$ weliswaar onder het gemiddelde in de EU (48,3\%), maar in de rangschikking neemt Nederland toch een middenpositie in. Samengevat, wat betreft de spreiding van onderzoekers over de private en publieke sector vertoont Nederland een voor de EU typisch beeld, zij het dat binnen de publieke sector de overheid een in Europees perspectief grote rol speelt.

\subsection{De internationale arbeidsmarkt voor kenniswerkers}

Knelpunten op de Nederlandse arbeidsmarkt voor kenniswerkers kunnen verlicht worden door het aantrekken van hoogopgeleid personeel uit het buitenland. Tegelijkertijd kunnen knelpunten in andere landen ook leiden tot een uitstroom van kenniswerkers uit Nederland. Exacte gegevens over deze 'brain-drain-effecten' zijn niet beschikbaar, maar aan de hand van gegevens die verkregen zijn in het kader van het door het Institute for Employment Studies (IES) en ROA samengestelde rapport Assessing the Supply and Demand for Scientists and Technologists in Europe (Pearson et al., 2001), kan toch een beeld worden geschetst van de Europese arbeidsmarkten voor R\&D-personeel.

Uit de IES Survey of R\&D Establishments (tabel 6.4) blijkt dat op de arbeidsmarkten voor R\&D-personeel in de Europese Unie meer knelpunten worden ervaren voor senior-onderzoekers en projectleiders dan voor technisch assistenten en junior onderzoekers. Met name overheidsinstellingen hebben moeite de hogere R\&Dposities gevuld te krijgen.

Tabel 6.4

Knelpunten in de R\&D-personeelsvoorziening in de EU naar functieniveau, 1998

\begin{tabular}{lcccc}
\hline & Bedrijfsleven & Overheid & Universiteiten & Totaal \\
\hline Technisch assistenten & 2.8 & 2.6 & 2.9 & 2.8 \\
Junior onderzoekers & 2.4 & 2.7 & 2.7 & 2.6 \\
Senior onderzoekers & 3.7 & 4.1 & 3.4 & 3.6 \\
Projectleiders & 3.7 & 4.2 & 3.9 & 3.8
\end{tabular}

Schaal van 1 ('easy to fill this type of research post') tot 5 ('difficult to fill this type of research post').

Bron: IES Survey of R\&D Establishments; Table 4.1 van Pearson et al. (2001)

Als we kijken naar studierichting (tabel 6.5) blijkt er vooral een schaarste aan R\&Dpersoneel met wetenschappelijke kennis op het gebied aan 'techniek en 
materiaalwetenschappen' en 'wiskunde en informatica' te bestaan. Overigens heeft de IES Survey of R\&D Establishments alleen betrekking op beta-wetenschappen, dus informatie over de schaarste aan R\&D-personeel met een economische of andere maatschappijwetenschappelijke achtergrond is niet beschikbaar.

Tabel 6.5

Knelpunten in de R\&D-personeelsvoorziening in de EU naar wetenschappelijke vaardigheden, 1998

\begin{tabular}{lcccc}
\hline & & & 3.0 & 2.9 \\
Natuurwetenschappen & 2.8 & 2.9 & 3.2 & 3.2 \\
$\begin{array}{l}\text { Wiskunde en informatica } \\
\text { Techniek en }\end{array}$ & 3.1 & 3.4 & 3.3 \\
materiaalwetenschappen & 3.2 & 3.4 & 3.3 & 2.8 \\
$\begin{array}{l}\text { Biologie en biomedische } \\
\text { wetenschappen }\end{array}$ & 2.7 & 2.9 & 2.8 & 2.8 \\
Milieuwetenschappen & 2.8 & 2.8 & 2.9 &
\end{tabular}

Schaal van 1 ('easy to recruit these skills') tot 5 ('difficult to recruit these skills').

Bron: IES Survey of R\&D Establishments; Table 4.2 van Pearson et al. (2001)

Tabel 6.6

Belangrijkste recruteringsbronnen voor onderzoekers, EU, 1998

\begin{tabular}{|c|c|c|c|c|}
\hline Recruteringsbron & Bedrijfsleven & Overheid & Universiteiten & Totaal \\
\hline Recente promovendi uit eigen land & 3.3 & 3.8 & 3.9 & 3.6 \\
\hline $\begin{array}{l}\text { Recent afgestudeerden uit eigen } \\
\text { land } \\
\text { Andere R\&D-organisaties in eigen }\end{array}$ & 3.6 & 3.9 & 3.4 & 3.6 \\
\hline land & 3.1 & 3.2 & 2.7 & 3.0 \\
\hline Gesponsorde studenten & 2.9 & 3.3 & 2.7 & 2.9 \\
\hline $\begin{array}{l}\text { Recente postdoc's } \\
\text { Recente promovendi uit andere }\end{array}$ & 2.3 & 3.3 & 2.8 & 2.7 \\
\hline $\begin{array}{l}\text { EU-landen } \\
\text { Andere onderdelen van de eigen }\end{array}$ & 2.2 & 2.7 & 3.0 & 2.6 \\
\hline organisatie & 2.4 & 2.3 & 2.3 & 2.4 \\
\hline $\begin{array}{l}\text { Recent afgestudeerden uit } \\
\text { andere EU-landen } \\
\text { Andere R\&D-organisaties in }\end{array}$ & 2.3 & 2.4 & 2.2 & 2.3 \\
\hline $\begin{array}{l}\text { andere EU-landen } \\
\text { Recente promovendi uit niet-EU- }\end{array}$ & 2.4 & 2.3 & 2.1 & 2.3 \\
\hline $\begin{array}{l}\text { landen } \\
\text { R\&D-organisaties uit niet-EU- }\end{array}$ & 1.7 & 2.0 & 2.4 & 2.0 \\
\hline $\begin{array}{l}\text { landen } \\
\text { Recent afgestudeerden uit niet- }\end{array}$ & 1.9 & 1.7 & 1.8 & 1.8 \\
\hline $\begin{array}{l}\text { EU-landen } \\
\text { Andere niet-R\&D-functies of }\end{array}$ & 1.7 & 1.7 & 1.7 & 1.7 \\
\hline pensioen & 1.6 & 1.5 & 1.4 & 1.6 \\
\hline
\end{tabular}

Schaal van 1 tot 5 met 5 'the most important'. Afgestudeerden zijn 'recent non-PhD level university graduates'. Vetgedrukt zijn alle vormen van internationale recrutering. Bron: IES Survey of R\&D Establishments, Table 2.3 van Pearson et al. (2001)

Bij het recruteren van de harde kern van het R\&D-personeel, de onderzoekers (tabel 6.6), blijken Europese werkgevers toch vooral in eigen land te zoeken, zowel onder recente promovendi en andere afgestudeerden als onder onderzoekers die 
werkzaam zijn bij andere werkgevers. Voor buitenlandse onderzoekers wordt door bedrijfsleven en overheid meer binnen dan buiten de EU gezocht. Universiteiten daarentegen hebben een voorkeur voor recente promovendi van zowel binnen als buiten de EU.

Tabel 6.7

Knelpunten op de arbeidsmarkten voor onderzoekers in de verschillende lidstaten van de EU naar studierichting, 1997-2002

\begin{tabular}{|c|c|c|c|}
\hline Lidstaat & Tekorten aan onderzoekers & $\begin{array}{l}\text { Effectiviteit van } \\
\text { binnenlandse } \\
\text { aanpassings- } \\
\text { processen }\end{array}$ & $\begin{array}{l}\text { Mogelijke } \\
\text { buitenlandse } \\
\text { recruterings- } \\
\text { bronnen }\end{array}$ \\
\hline België & Geen & - & - \\
\hline Denemarken & Natuurwetenschappen & Beperkt & $\begin{array}{l}\text { Griekenland, } \\
\text { Spanje, Italï̈ }\end{array}$ \\
\hline \multirow[t]{2}{*}{ Duitsland } & Natuurwetenschappen & Beperkt & $\begin{array}{l}\text { Griekenland, } \\
\text { Spanje, Italië }\end{array}$ \\
\hline & Medische wetenschappen & Voldoende & - \\
\hline Griekenland & Geen & - & - \\
\hline Spanje & Geen & - & - \\
\hline Frankrijk & Natuurwetenschappen & Voldoende & - \\
\hline lerland & Medische wetenschappen & Beperkt & $\begin{array}{l}\text { Verenigd } \\
\text { Koninkrijk }\end{array}$ \\
\hline Italië & Medische wetenschappen & Voldoende & - \\
\hline \multirow[t]{2}{*}{ Nederland } & Natuurwetenschappen & Beperkt & $\begin{array}{l}\text { Griekenland, } \\
\text { Spanje, Italië }\end{array}$ \\
\hline & Medische wetenschappen & Beperkt & Frankrijk \\
\hline \multirow[t]{2}{*}{ Oostenrijk } & Natuurwetenschappen & Voldoende & - \\
\hline & Medische wetenschappen & Beperkt & Frankrijk \\
\hline Portugal & Natuurwetenschappen & Voldoende & - \\
\hline Finland & Geen & - & - \\
\hline \multirow[t]{4}{*}{ Zweden } & Natuurwetenschappen & Voldoende & - \\
\hline & Technische wetenschappen & Voldoende & - \\
\hline & Medische wetenschappen & Voldoende & - \\
\hline & Landbouwwetenschappen & Voldoende & - \\
\hline $\begin{array}{l}\text { Verenigd } \\
\text { Koninkrijk }\end{array}$ & Geen & - & - \\
\hline EU & Geen & Voldoende & - \\
\hline
\end{tabular}

Bron: Table 15, Marey, de Grip \& Cörvers (2001)

Een indicatie voor huidige knelpunten op de verschillende Europese arbeidsmarkten (per lidstaat en per studierichting) voor onderzoekers wordt gegeven door prognoses voor de periode 1997-2002 die gemaakt zijn in een pilot-study van Marey, de Grip \& Cörvers (2001). Het doel van deze pilot-study in het kader van het project Assessing the Supply and Demand for Scientists and Technologists in Europe was het inventariseren van de mogelijkheden, gegeven de huidige beschikbaarheid van data, om prognoses te maken van de Europese arbeidsmarkten voor onderzoekers naar lidstaat en naar studierichting. Aangezien de prognoses betrekking hadden op de periode 1997-2002 kunnen ze gebruikt worden als 'nowcasts' voor de huidige knelpunten. Hierbij moet wel worden opgemerkt dat de voor een gedegen 
prognosestudie benodigde data slechts beperkt beschikbaar waren en soms ook van magere kwaliteit. Voor een betrouwbaar (en gedetailleerder) beeld van de huidige en toekomstige knelpunten in Nederland kan men zich dan ook beter op hoofdstuk 2 en 3 baseren.

Voor veertien landen van de EU zijn voorspellingen gemaakt van uitbreidingsvraag, vervangingsvraag en instroom van onderzoekers naar vier studierichtingen: natuurwetenschappen, technische wetenschappen, medische wetenschappen en landbouwwetenschappen. Alpha- en gamma-wetenschappen maakten geen deel uit van de studie. Confrontatie tussen de verwachte ontwikkelingen in vraag en aanbod geven een indicatie van de knelpunten op de verschillende Europese arbeidsmarkten voor onderzoekers (tabel 6.7). Vervolgens werd gekeken in hoeverre binnenlandse aanpassingsprocessen eventuele tekorten zouden kunnen opvangen. Aan de vraagzijde gaat het hierbij om reducties in het aantal uren dat onderzoekers aan nietR\&D-activiteiten besteden door een herverdeling van werk (bijvoorbeeld tussen mensen die informatica gestudeerd hebben en andere academici die werkzaam zijn in de IT branche) en het verlengen van de werkweek. Aan de aanbodzijde kan het gaan om een verhoging van het percentage afgestudeerden dat voor een baan als onderzoeker kiest door R\&D aantrekkelijker te maken voor afgestudeerden of substitutie tussen onderzoekers met een achtergrond in technische wetenschappen en natuurwetenschappen, bijvoorbeeld chemisch technologen opgeleid aan technische universiteiten en chemici opgeleid aan 'gewone' universiteiten. Voorzover deze aanpassingsprocessen in eigen land onvoldoende waren is ook gekeken naar verwachte overschotten voor bepaalde studierichtingen in andere lidstaten van de EU als mogelijke buitenlandse recruteringsbronnen.

De uitkomsten van de pilot-study geven aan dat het hoger onderwijs in de EU in alle vier studierichtingen voldoende afgestudeerden levert om in de verwachte vraag naar onderzoekers in de periode 1997-2002 te voorzien. ${ }^{19}$ Tekorten doen zich naar verwachting wel voor op het niveau van de verschillende lidstaten. Het belang van internationale arbeidsmobiliteit voor onderzoekers binnen de EU komt derhalve duidelijk naar voren in de resultaten. Op het gebied van natuurwetenschappen zijn er tekorten in Denemarken, Duitsland en Nederland die gecompenseerd zouden kunnen worden door overschotten in Griekenland, Spanje en Italië. De tekorten aan natuurwetenschappers in Frankrijk, Oostenrijk, Portugal en Zweden kunnen door binnenlandse aanpassingsprocessen opgevangen worden. Voor medische wetenschappen worden er tekorten verwacht in lerland, Nederland en Oostenrijk. Met name Frankrijk heeft daarentegen een overschot waar Nederland en Oostenrijk gebruik van zouden kunnen maken. Voor lerland zou het overschot in het Verenigd Koninkrijk het meest voor de hand liggen. Voor de verwachte tekorten aan medische wetenschappers in Duitsland, Italië en Zweden hoeft waarschijnlijk geen beroep op internationale arbeidsmobiliteit te worden gedaan. Tekorten voor technische en landbouwwetenschappen worden alleen verwacht voor Zweden, waar de binnenlandse aanpassingsprocessen naar verwachting afdoende zijn.

19. Uiteraard moet worden opgemerkt dat de afwezigheid van tekorten voor bijvoorbeeld de technische wetenschappen als geheel gepaard kan gaan met tekorten voor specifieke opleidingstypen als werktuigbouwkunde of informatica. 



\section{Conclusie}

Nederland heeft een in Europees perspectief groot wetenschappelijk en technologisch arbeidspotentieel (HRST-groep), waarbij het MBO een relatief belangrijke rol speelt. Tegelijkertijd is er ook een grote vraag naar met name hoger opgeleid personeel. Het gevolg is dat er knelpunten op de arbeidsmarkt voor kenniswerkers zijn, waardoor het innovatief vermogen van de Nederlandse economie afgeremd wordt. Naar verwachting zullen er tot 2006 ernstige knelpunten blijven optreden in de meeste HRST-beroepen en de meeste onderzoeksberoepen. Dit heeft ook tot gevolg dat bedrijfsleven, overheid en universiteiten in een sterke concurrentie verwikkeld zijn om de schaarse kenniswerkers. Knelpunten lijken voor een deel te worden opgelost door de instroom van buitenlandse kenniswerkers, met name bij universiteiten. Desalniettemin recruteren Europese werkgevers toch vooral in eigen land, ook al lijken er voor bepaalde vakgebieden overschotten in het ene land te zijn die tekorten in een ander land zouden kunnen compenseren. De verwachte knelpunten op de arbeidsmarkt voor kenniswerkers tot 2006 kunnen de aantrekkingskracht van Nederland op kennisintensieve bedrijven en instellingen - zowel Nederlandse als buitenlandse - beperken. In Nederland zijn in vergelijking met andere lidstaten van de Europese Unie relatief weinig onderzoekers werkzaam, waardoor er dus weinig mensen bezig zijn met het scheppen van nieuwe kennis. De verwachte tekorten aan onderzoekers tot 2006 kunnen als gevolg hebben dat een deel van eventuele extra R\&D-uitgaven tot hogere lonen van kenniswerkers leiden in plaats van extra onderzoekers. 



\section{Literatuur}

Bos, J. \& Keizer, M., De academische arbeidsmarkt in cijfers en trends, Onderdeel van de Arbeidsmarktmonitor Kennissector 2001, Eindrapport, Research voor Beleid, B2440, Leiden, 2001.

Bresnahan, T.F., Brynjolfsson, E. \& Hitt, L.M., Information technology, workplace organization, and the demand for skilled labor: firm level evidence, Quarterly Journal of Economics, 2001.

Centraal Bureau voor de Statistiek, Standaard Beroepenclassificatie 1992, Den Haag, 1993.

Centraal Bureau voor de Statistiek, Kennis en economie 2000, Voorburg/Heerlen, 2000.

Centraal Bureau voor de Statistiek, Kennis en economie 2001, Voorburg/Heerlen, 2001.

Centraal Planbureau, Omgevingsscenario's Lange Termijn Verkenning 1995-2020, Werkdocument No. 89, Den Haag, 1996.

Centraal Planbureau, Centraal Economisch Plan 2001, Den Haag, 2001.

Cörvers, F., The impact of human capital on international competitiveness and trade performance of manufacturing sectors, ROA Dissertation Series 2, Maastricht, 1999.

Dijk, M., van \& Webbink, D., Shortages of scientists, CPB Report 00/4, CPB, Den Haag, 2000.

Grip, A., de, Meijboom, P. \& Willems, E., Vacancies, employment growth and the demand for newcomers on the labour market, in: Measurement and analysis of job vacancies, J. Muysken (ed.), Avebury., Aldershot/Brookfield, USA, 1994, pp. 1-1-125.

Jacobs, D., Het kennisoffensief: slim concurreren in de kenniseconomie, Tweede, uitgebreide editie, Samsom, Deventer/Alphen aan den Rijn, 1999.

Koninklijk Instituut van Ingenieurs, Ingenieur en Salaris, Den Haag, 1998.

Koninklijk Instituut van Ingenieurs, KIvI Salarisrapport 2001, Den Haag, 2001.

Machin, S. \& van Reenen, J., Technology and changes in skill structure: evidence from seven OECD countries, Quarterly Journal of Economics, vol. 113, 1998, pp. 1245-1279.

Marey, P., Crowding out in the Dutch labour market for R\&D workers, ROA-R-2002/6E, Maastricht, 2002.

Marey, P. \& Borghans, L., Wage elasticities of the supply of knowledge workers in the Netherlands, ROA-R-2000/6E, Maastricht, 2000.

Marey, P., de Grip, A. \& Cörvers, F., Forecasting the labour markets for research scientists and engineers in the European Union, ROA-W-2001/3E, Maastricht, 2001.

Minne, B., Onderzoek, ontwikkeling en andere immateriële investeringen in Nederland, Centraal Planbureau, Den Haag, 1995.

Murphy, K., Shleifer, A. \& Vishny, R. The allocation of talent: implications for growth, Quarterly Journal of Economics, 98, 1991, pp. 503-530.

OECD, Draft Manual on the Measurement of Human Resources devoted to S\&T, Parijs, 1993.

Oosterbeek, H. \& Webbink, D., Is there a hidden technical potential? De Economist, 145, p. 159-177, 1997.

Pearson, R., Jagger, N., Connor, H., Marey, P., de Grip, A., Cörvers, F., Assessing the Supply and Demand for Scientists and Technologists in Europe, IES Report 377, Brighton, U.K., 2001. 
ROA, De arbeidsmarkt naar opleiding en beroep tot 2006, ROA-R-2001/8, Maastricht, 2001.

ROA, ROA-classificatiegids 2002, ROA-R-2002/3, Maastricht, 2002.

Wieling, M. \& Borghans, L., Discrepancies between supply and demand and adjustment processes in the labour market, Labour, vol. 15, 2001, pp. 33-56. 